$1-1-1967$

\title{
Posting of land in West Virginia and landowner attitudes regarding posting, hunting fees, and the hunter
}

Kenneth D. McIntosh

Follow this and additional works at: https://researchrepository.wvu.edu/ wv_agricultural_and_forestry_experiment_station_bulletins

\section{Digital Commons Citation}

McIntosh, Kenneth D., "Posting of land in West Virginia and landowner attitudes regarding posting, hunting fees, and the hunter" (1967). West Virginia Agricultural and Forestry Experiment Station Bulletins. 542.

https://researchrepository.wvu.edu/wv_agricultural_and_forestry_experiment_station_bulletins/496 @ WVU. It has been accepted for inclusion in West Virginia Agricultural and Forestry Experiment Station Bulletins by an authorized administrator of The Research Repository @ WVU. For more information, please contact ian.harmon@mail.wvu.edu. 
West Virginia University Libraries

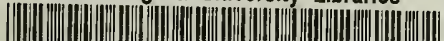

I.|.

308021009521343 



\section{POSTING Of LANDIN WEST VIRGINIA}

AND LANDOWNER ATTITUDES REGARDING POSTING, HUNTING FEES, AND THE HUNTER

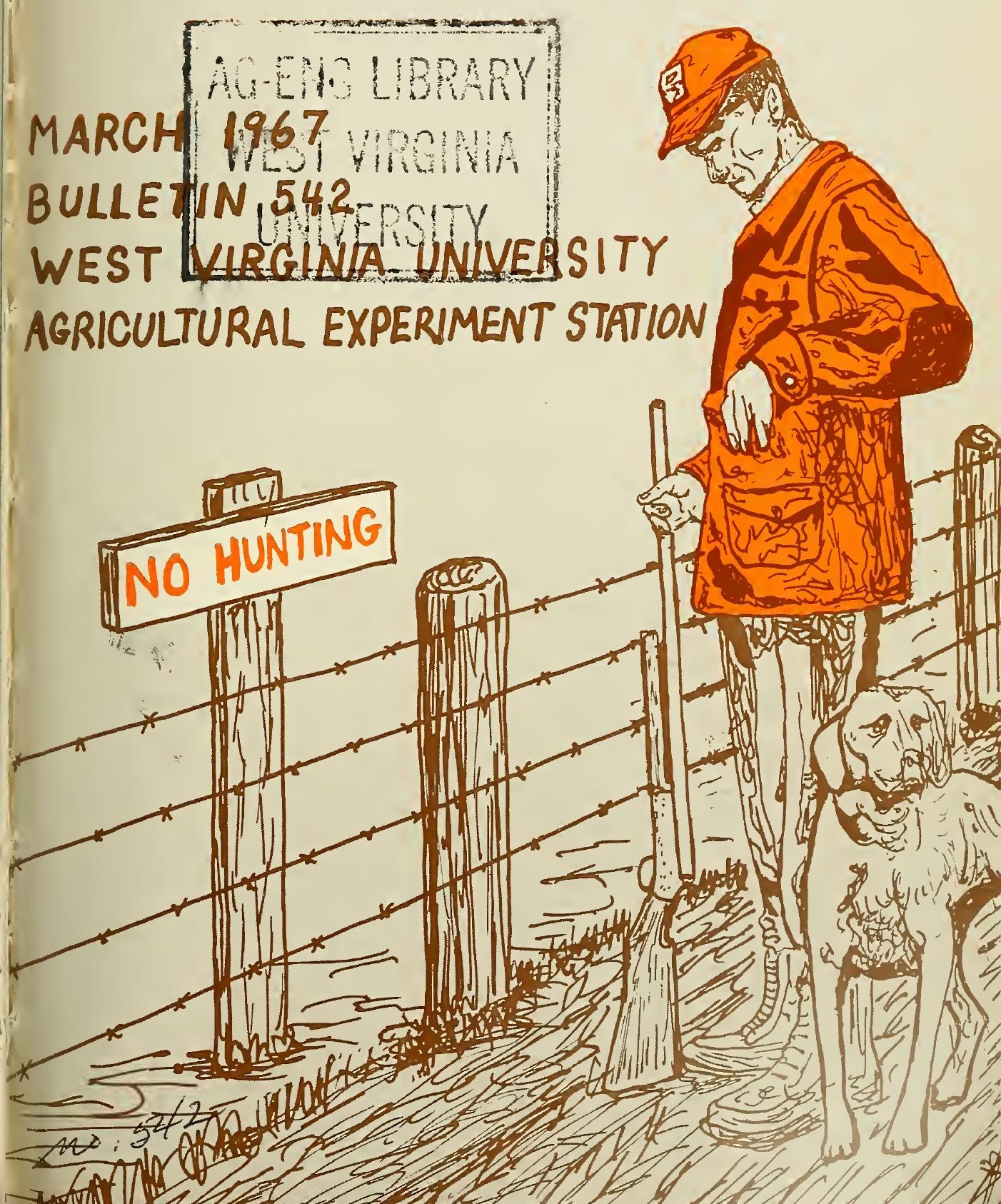





\section{Contents}

Summary -

Introduction _._- 5

Gaining Access to Public and Privately Owned Hunting Lands _-_-_-_._- 10

Statement of Objectives _..._. 11

Extent of Posting in West Virginia (Sample Survey Results)

Testing the Significance of Variations in the

Proportions of Land Posted Among Counties and Regions _._.......-_ 14

Relation Between Posting and Size of Landholding _-_._-_._-_._._._._. 14

Relation of Posting to Hunter Damages _._._. 16

Relation of Posting to Wildlife Damages _._. 18

Posting Experience of Landowners Who Do Not

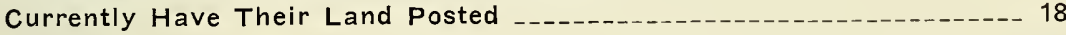

Seasonal Posting of Land _._- 18

Length of Current Post

Landowner Reasons for Posting of Land _-_._._. 22

Attitudes and Opinions of Landowners Regarding

Their Right to Post Land

Discrimination Among Hunters by West Virginia Landowners _..._._._._. 27

Admission Requirements to Hunt on Privately Owned Lands -_-_-_-_-_-_ 29

Legal Provisions for Excluding Hunters on Privately Owned Land -...---- 30

Unwritten Rules and Values that Influence Landowner Decisions to

Allow Public Hunting on Privately Owned Lands _..... 32

Marketing of Hunting Rights in West Virginia

(Sample Survey Results) - 33

Attitudes of Landowners on the Assessment of Hunting Fees _._._._._. 33

Reasons for Opposition to Hunting Fees

Reasons for Favoring Hunting Fees -

Willingness of Landowners to Charge Hunting Fees _-_._. 37

Landowner Estimates of Fees that Should be Assessed on Hunters _..._. 37

Brief Review of Landowner Attitudes on the Assessment of Hunting Fees _- 38 


\section{THE AUTHOR}

Kenneth D. Mcintosh is Assistant Agricultural Economist.

West Virginia University

Agricultural Experinient Station

College of Agriculture and Forestry

A. H. Vanlandingham, Director

MoRgantown 


\section{SUMMARY}

Privately owned land accounts for approximately 90 per cent of the hunting land in West Virginia. Historically, these private owners have followed a policy of open and free use of their land for hunting. However, the proportion of land under post has been increasing. Approximately 47 per cent of the current postings were made within the last five years and two-thirds within the last ten years. At the present time, 29 per cent of the landowners have their lands posted; 2 per cent practice seasonal posting and 27 per cent maintain a continuous post. In addition to these landowners who currently post their lands, another 20 per cent of the landowners have posted sometime in the past.

Among the three regions of West Virginia, posting of land is most important in the Eastern region, of least importance in the Southern region, and of intermediate importance in the Northwestern region. Among the counties in the survey, posting is most important in Hampshire, Marshall, Berkeley, and Pendleton, and of least importance in Wyoming, Fayette, Lincoln, Monroe, and Doddridge.

Posting of land is associated with the size of landholding. Landowners with small holdings (less than 100 acres) post less often and owners with large holdings (over 500 acres) more often than intermediate size holdings ( 100 to 500 acres). Posting is associated also with hunter damage to the property of landowners. The frequency of posting among those who have been damaged by hunters is more than double the frequency of posting among those who have not been damaged by hunters. The frequency of posting seems unrelated to damage from wildlife.

Among those landowners with posted land, a majority indicated that they use posting to assist in restriction and selection among would-be hunters. A third of those who post stated that fear of damages to property, livestock, fences, and person motivated them to erect posting signs. Approximately one-fourth of those with posted land stated that they posted because they had incurred damages to livestock, fences, trees, and other property.

Landowner attitudes or opinions of why they should have the right to post indicate that the exertion of the legal right to exclude, which accompanies ownership of land, is most important, followed by protection of person and property, selection among users, control of total number of users, and the conservation and protection of wildlife.

Landowners who post, practice a more selective policy among hunters than owners who do not post. Only 14 per cent of those who post allow anyone to hunt on their land, compared to 73 per cent of those who do not post. 
The legal Codes of West Virginia sanction the right of landowners to exclude hunters from their land and make it illegal to hunt on fenced or posted lands without the owner's written permission. However, traditional values and the custom of open and free hunting is very strong among landowners and 91 per cent will allow hunters to hunt on their lands with no greater requirement than oral permission. Approximately 43 per cent of the landowners allow hunters to use their land without even asking permission, 39 per cent require oral permission, 3 per cent written permission, 9 per cent either oral or written permission, 1 per cent club membership, and 5 per cent do not allow hunting by anyone.

Attitudes on the assessment of hunting fees reflect the extent to which landowners adhere to the traditional values of open and free hunting for everyone. Approximately 70 per cent of those interviewed do not believe that hunting fees should be levied on hunters, and most of this opposition stems from traditional views and beliefs. Reasons given in support of this attitude or belief were qualified by those who do not wish to pay a hunting fee themselves, by those who would restrict hunters through other means, by those who own poor quality hunting lands, and by those who have equity considerations in mind. The latter would favor hunting fees if a landowner incurs expense to provide better quality hunting. In addition to widespread opposition to hunting fees, only 18 per cent of the landowners indicated that they would be willing to grant hunting privileges for a fee.

Landowner attitudes appear to be changing in the direction of a market orientation toward hunting rights on land. However, this change is not yet a significant phenomenon in West Virginia. The evolution toward the selling of what has been a free service (free entry to private lands for hunting) is manifested in the contractural arrangements that 1 per cent of the landowners have with hunting clubs and the 3 landowners who are assessing fees on hunters. 


\section{Posting of Land in West Virginia and Landowner Attitudes Regarding Posting, Hunting Fees, and the Hunter}

KENNETH D. MCINTOSH

G AINING access to hunting lands in West Virginia is primarily a matter of gaining entry to privately owned land. According to the United States Department of Commerce there are 15,410,746 acres of land in the State and approximately 90 per cent of the acreage $(13,720,548)$ is privately owned (Table 1). The State and Federal governments own, or control through leasing arrangements with private owners, slightly more than 7 per cent of the total land area (1,142,198 acres), most of which can be used for public hunting.

As indicated in Table 2, the acreage of State owned or leased land, designated as public hunting areas, has increased tenfold over the past 20 years. In 1945 these areas accounted for 16,000 acres, but by 1965 they had been expanded to 160,000 acres, and while relatively small when compared to total land area in the State, they are widely dispersed (Figure 1 and Tables 3 and 4 ). In addition to the designated public hunting areas, the State owns 76,800 acres of land in State Forests which also are used for public hunting. These areas have expanded approximately 23 per cent over the period 1945-1965.

The largest holding of publicly owned hunting land is in the George Washington and Monongahela National Forests. These two forests contain approximately 904,000 acres in West Virginia, an area that has remained unchanged over the past 20 years.

In spite of the rapid increases noted in public hunting areas over the past 20 years, the fact remains that 90 per cent of the land in West Virginia remains under the control of private landowners. In past years an overwhelming majority of these owners have granted hunters free access to their lands. Furthermore, there is no evidence that the generosity of private landowners will undergo abrupt and serious transformation in the very near future. However, from a longer run perspective there are reasons to suspect that the institution of open and free hunting on private lands will be gradually modified and assume a market orientation very similar to the markets that we have today for other goods and 


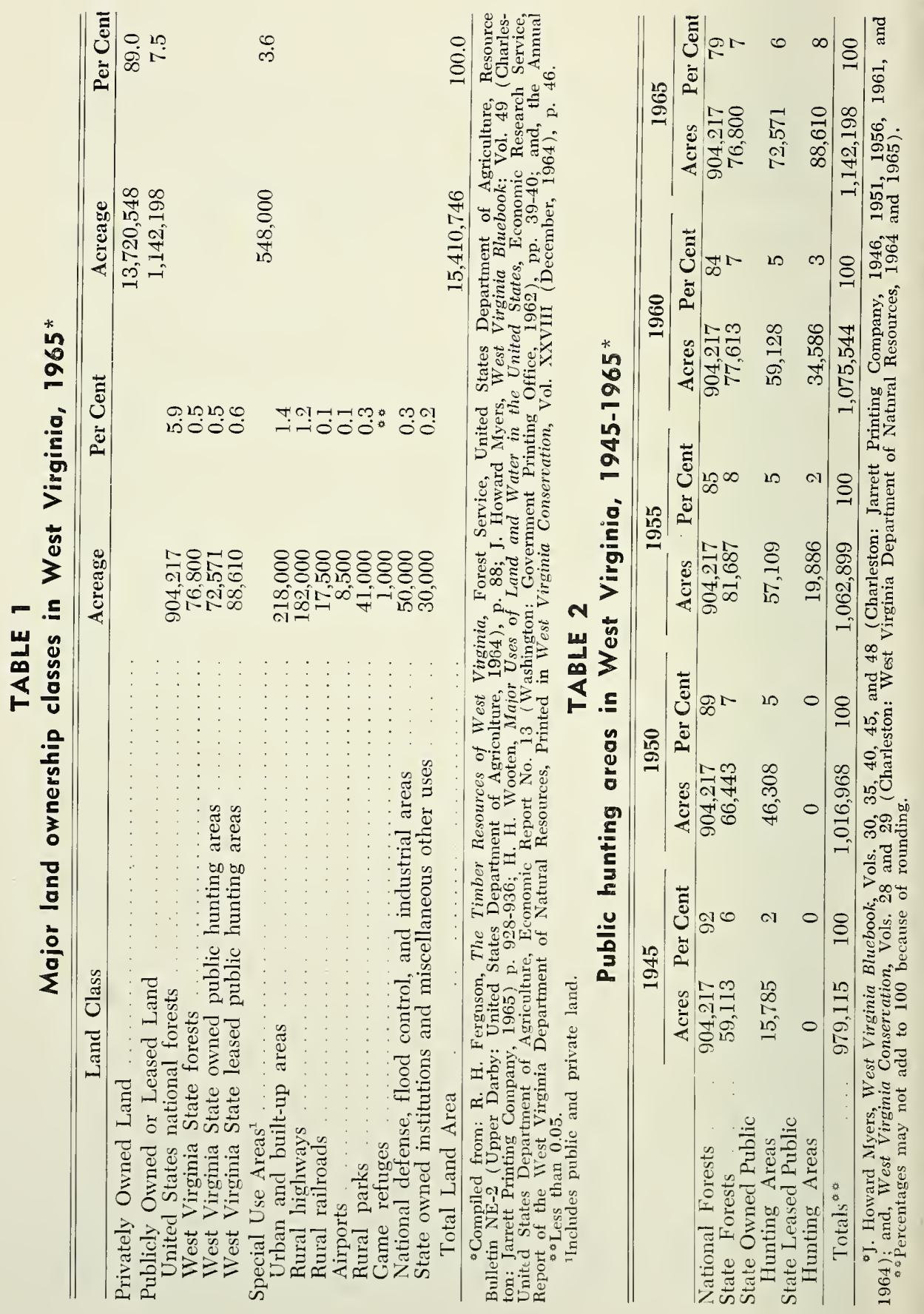


services. Some of the longer run forces which are involved in this evolutionary process are:

1. Increasing population, especially in nearby states.

2. Increasing real per capita income.

3. Increasing leisure time.

4. Improvements in highways and means of transportation.

5. Increasing number of hunters.

6. Increasing land taxes.

7. Competition among land uses.

At first glance, these trends, which are primarily associated with demand, make it appear that private landowners, over the long run will be in a position to capture monetary and employment benefits from what has been traditionally a free service. However, income and employment opportunities are functionally related to both supply and demand. Market values and prices result from the interaction of supply and demand and a partial analysis of either one alone, is, in a Marshallian sense,

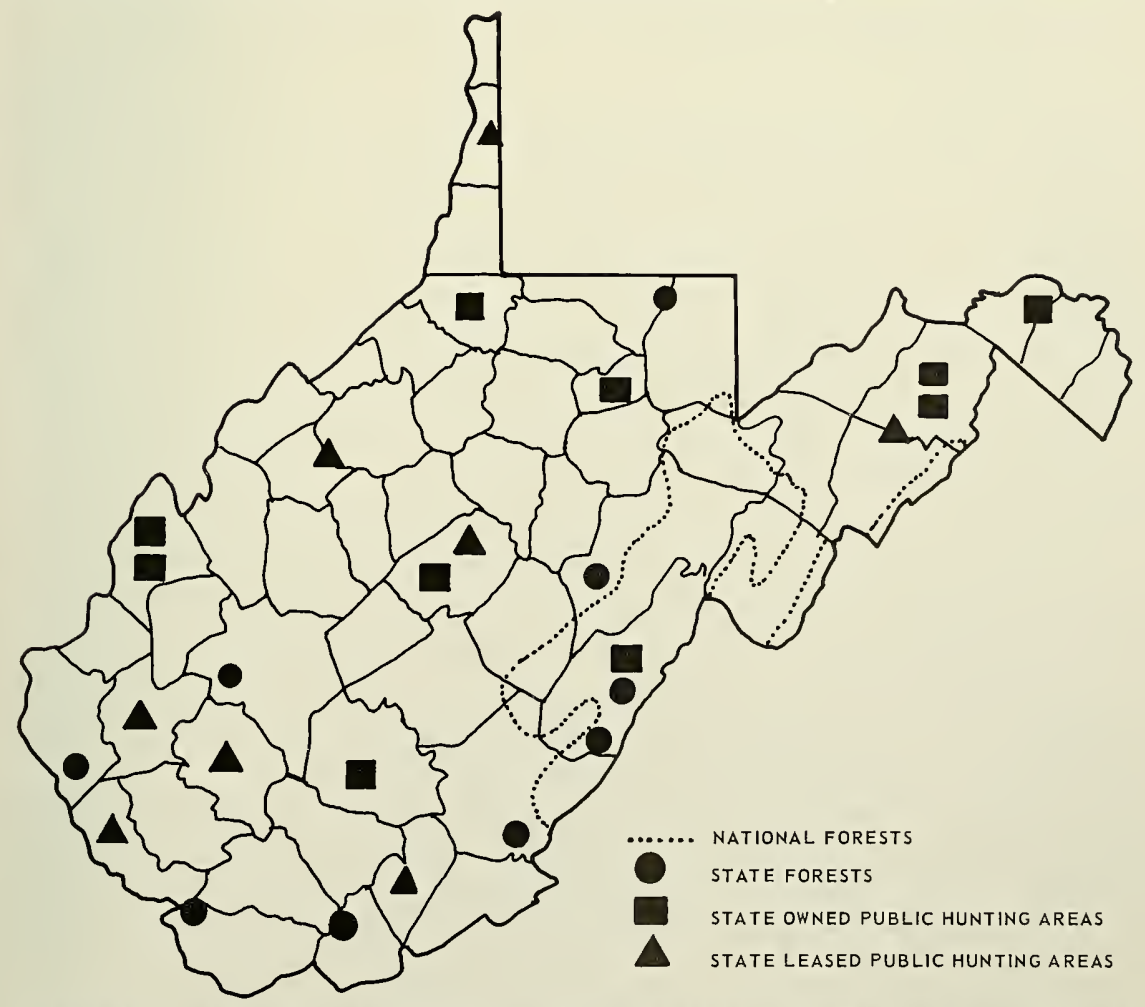

FIGURE 1. Location of Public Hunting Areas in Wesf Virginia, 1965 
an attempt to cut cloth with but one blade of the scissors. Nevertheless, in situations where there are no markets or prices, or where they are evolving, partial analysis may be the best alternative to provide understanding, insight, and useful information.

What type of evidence is necessary to either support or reject the contention that the long run evolution of viable markets for hunting rights is occurring in West Virginia? In the first instance, a market cannot be adequately defined in economic terms without reference to price. In those circumstances where goods or services do not bear prices they are known as free goods or services, and markets (as spheres where supply and demand forces are interacting in the establishment of price levels) are nonexistent. Goods and services have prices because they are useful and are scarce relative to alternative uses to which they can be put. Historically the use of privately owned land for hunting purposes has fallen into the category of free goods and services. Thus, in order to

\section{TABLE 3}

\section{State owned public hunting areas in West Virginia, 1965*}

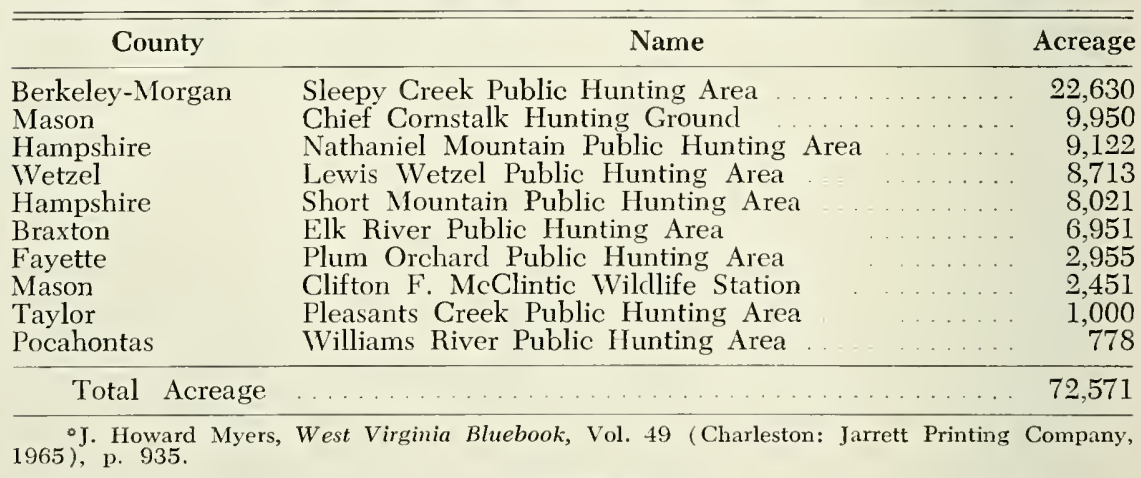

TABLE 4

State leased public hunting areas in West Virginia, 1965*

\begin{tabular}{|c|c|c|}
\hline County & Name & Acreage \\
\hline Hardy-Hampshire & J. M. Huber (Operation Lands) ... .... & 20,000 \\
\hline Summers & Bluestone Reservoir Public Hunting Area & 19,886 \\
\hline Mingo & Laurel Lake Public Hunting Area .... & 12,000 \\
\hline Wirt-Ritchie & Hughes River Public Hunting Area & 10,000 \\
\hline Boone & Fork Creek Public Hunting Área & 9,000 \\
\hline Lincoln & Big Ugly Public Hunting Area & 5,700 \\
\hline Braxton & Army Corps of Engineers & 6,789 \\
\hline Brooke & Brooke County Cooperative Area & 5,235 \\
\hline Total Acreage & & 88,610 \\
\hline
\end{tabular}


create markets for hunting rights, there must be scarcity, real or imagined, relative to demand. This implies that restrictions must be made in the quantity of land that can be used at zero price before markets will become a reality. It is postulated that such restrictions are being made in West Virginia and can be noted in a study of prevailing access arrangements for privately owned land. Furthermore, it is contended that such restrictions are manifestation of the long run evolution of prices and markets for hunting rights on privately owned land. For example, the posting of private land against trespassing generally and hunting specifically is a restriction in the aggregate supply of hunting land. Thus, if the incidence of posting is increasing it seems logical to infer that at some future date this process will assist in the establishment of prices and markets for hunting rights.

Some of the more important questions which are associated with a study of access arrangements are as follows:

What is the incidence of posting? Is it increasing, decreasing, or remaining stable? How much of the total land area that is used for hunting can be used free of charge? What is the extent of fee assessing by landowners? How many landowners have leased their lands to hunting clubs? What are landowner attitudes regarding hunting fees? What is the source of these attitudes? What are access conditions on posted lands?

As indicated in an earlier publication, ${ }^{1}$ if we assume that there is a hunting demand, there are important supply considerations which can affect the ability of private landowners to earn income and employment from the marketing of hunting rights. Chief among these factors is the quality of hunting lands, the supply of free hunting lands, and landowner attitudes regarding the assessment of hunting fees.

To obtain necessary information for analyzing these supply characteristics, the West Virginia Agricultural Experiment Station initiated a hunting and fishing research project in 1965. As a part of this research effort a random sample of West Virginia landowners was personally interviewed in the spring and summer of 1965. In the first report arising from this project it was indicated that the quality of privately owned hunting lands is relatively low for most species of wildlife in most areas of the State. ${ }^{2}$ As noted in the earlier publication this situation is primarily the result of natural succession and accompanying wildlife habitat destruction on lands that have been abandoned for farming purposes. In the following report primary emphasis is given to a compilation and analysis of access arrangements existing on privately owned land and the attitudes of landowners regarding the assessment of hunting fees.

${ }^{1}$ Hunting Quality of Privately Owned Lands in West Virginia, Kenneth D. McIntosh, West Virginia University Agr. Exp. Sta. Bull. 539, Dec., 1966.

IIbid. 


\section{Gaining Access to Public and Privately Owned Hunting Lands}

On the publicly owned land, access for hunting is normally conditioned on the purchase of licenses, or stamps, and the abiding by rules and regulations with regard to hunting seasons, bag limits, littering, fire control, etc. However, entry to privately owned land is conditioned not only by licenses, rules and regulations, but by the desires of private landowners. Landowners have the legal right to exclude others from their land, and this right places them in a position to determine not only who hunts upon their land but the terms under which such users will be admitted.

Historically, landowners have been quite liberal in keeping their lands open and in allowing the hunting public to use their lands free of charge. In more recent times, however, there has been a movement away from open and free hunting lands not only in West Virginia but elsewhere in the nation. ${ }^{3}$ For the most part, this break with tradition has taken the form of leased lands to private hunting clubs, various forms of fee hunting, including private hunting preserves and, more importantly, posted land. As noted in ORRRC study Report 6, "Posting of private land is said to be very important in 24 states and important in 18 others, of slight importance in 4 and of no importance in 1 state."

In West Virginia the closing of private land to open and free hunting is manifested in several ways. In addition to posting signs, some landowners follow the practice of advertising in newspapers that their lands are posted. ${ }^{5}$ In some areas of the State, hunting clubs have entered into contractural arrangements with private landowners whereby hunting rights are leased for exclusive use of club members. At the same time a few landowners have started charging fees for the use of their land. Another group of landowners, mostly farmers, have initiated a program whereby their homes are converted into boarding homes during the hunting season, and to provide better hunting for their fee-paying guests many of these landowners have posted their lands. Finally, four private hunting preserves have been established in recent years. ${ }^{6}$

3 Outdoor Recreation Resources Review Commission, Hunting in the United States-Its Present and Future Role, Study Rept. No. 6 (Washington: Government Printing Office, 1962), pp. 26-37. ${ }^{4}$ Ibid., p. 43.

${ }^{5}$ As the hunting season approaches each year, landowners advertise that their lands are posted. The following notice was published on October 20, 1965 in The Moorefield Examiner and Hardy County News, Moorefield, West Virginia:

"We have had our presses running at every opportunity during the past two or three weeks printing up posted notices. Landowners are anticipating the influx of many hunters, and especially during the two weeks deer season which starts the Monday before Thanksgiving this year, the earliest deer season we remember. Hunters are also bringing fishing gear this year for the trout streams have been restocked in the area. More and more landowners are posting land, not that they want to stop hunting, but they are entitled to know who is on their land. A few uncouth characters spoil hunting for many decent sportsmen. Forty-one per cent of all forest fires in the State last year were caused by careless hunters."

61964-1965 National Shooting Preserve Directory, prepared by National Shooting Sports Foundation, Inc., Riverside, Connecticut. This Directory indicates three privately owned shooting preserves in West Virginia, but it does not include the Sterling Shooting Preserve in Preston County. 
In spite of these general observations, very little effort has been made to obtain an overall assessment of posting in West Virginia. At the initiation of this study there were no quantitative data on the extent of posting, the charging of hunting fees, and the role of hunting clubs. In the nationwide survey of State Game and Fish personnel, the Outdoor Recreation Resources Review Commission found that posting was an important problem in most states, including West Virginia. ${ }^{7}$ However, these qualitative judgments were based primarily on estimates from conservation officers and State forestry personnel. No attempt was made to obtain a quantitative measure of posted land either by ORRRC or by personnel in the State Division of Game and Fish.

Posting studies have been conducted in several states and an excellent summary of the results is reported in ORRRC Study Report 6. ${ }^{8}$ As noted in the report, Michigan is the only state that has maintained an index of posted lands over an extended time period. The results of the Michigan studies indicate that posting in that state is not only relatively high in some areas but the incidence of posting has been increasing in recent years. Posting studies in other states such as California, Florida, Kentucky, and Massachusetts have determined acreages currently under post but an assessment of longer run trends is generally missing.

A general inadequacy of posting studies has been the failure to obtain an indication of hunting uses made of land that has been posted. Landowners post their lands for a variety of reasons and the presence of posting signs does not mean that no one is allowed to hunt on the posted land. Some landowners post their land to reduce the total number of hunters. Other landowners use posting as a means of providing better hunting lands for their close friends, family, and relatives. The presence of posting signs may indicate that the land has been leased by a hunting club that has posted the land for exclusive use by club members. As noted in the Massachusetts study, many landowners who have their lands posted would grant entry to would-be hunters if they would ask permission to hunt. ${ }^{9}$ Finally, there are landowners who use posting as a means of excluding all hunters from their land.

\section{Statement of Objectives}

Considering the lack of information on posted land in West Virginia, and on the terms of entry to privately owned land, either posted or not posted, a large portion of the landowner survey was designed to answer the following basic questions:

1. What proportion of West Virginia landowners have their lands under post?

${ }^{7}$ Outdoor Recreation Resources Review Commission, op. cit., p. 43.

sIbid., pp. 28-31.

OToseph S. Larson, "Straight Answers About Posted Land, "Twenty-Fourth North American Wildlife Conference, 1959, Transactions, pp. 480-487. 
2. Is the incidence of posting increasing or decreasing?

3. Why do landowners post their land?

4. Who is allowed to hunt on posted land?

5. What are the terms of entry to hunt on privately owned land, either posted or not posted?

Based on personal observations, judgments of personnel in the West Virginia Department of Natural Resources, and the results of posting studies in other states, it was estimated that perhaps as many as 40 per cent of all landowners had their lands under post. Further, it was believed that the incidence of posting had been increasing over the past five to ten years.

\section{Extent of Posting in West Virginia (Sample Survey Results)}

The survey results indicate that the estimate of landowners who had their lands under post was relatively high. At the time of the survey slightly more than a fourth ( 27 per cent) of those interviewed had their lands posted (Table 5). This 27 per cent is a slight underestimate of the proportion of landowners who actually post sometime during a year. Approximately 2 per cent of all landowners stated that they follow a practice of posting during the hunting season and after the season is over they remove the postings (Table 8 ). If an adjustment is made for these intermittent postings, about 29 per cent of all landowners post their land over a period of a year. In comparison, the results of a 1964 study in Pennsylvania indicate that approximately 40 per cent of the landowners in three Pennsylvania counties post their lands. ${ }^{10}$

It was anticipated that a significantly higher percentage of posting would be noted in those counties where hunting pressures are greatest (especially during deer season), where the highest quality hunting lands are located, and where there is a greater opportunity for damages to crops and livestock. With respect to these three items, counties in the Eastern region of West Virginia rank very high when compared to counties in the Southern or Northwestern regions. Furthermore, personal observations in the three regions leave the impression that a much higher proportion of landowners in the Eastern region post their land than in either of the other two regions.

As expected, the extent of posting varied considerably among counties and, to a lesser extent, among regions. Among counties the proportion of landowners who had their lands under post ranged from a low of 9 per cent in Wyoming County to a high of 40 per cent in Marshall County (Table 5). In three of the six counties in the Eastem region,

10"Significant Factors Influencing the Availability of Privately Owned Land to the Hunter," paper presented by John S. Barclay at the Northeast Fish and Wildlife Conference, Harrisburg,
Pa., Jan. 20,1965, p. 10 . 


\section{TABLE 5}

\section{Frequency of posting in West Virginia, sample survey of landowners, 1965}

\begin{tabular}{|c|c|c|c|c|}
\hline County & $\begin{array}{l}\text { Number of } \\
\text { Landowners } \\
\text { With Posted } \\
\text { Land }\end{array}$ & $\begin{array}{l}\text { Proportion } \\
\text { of Total } \\
\text { Landowners } \\
\text { in the } \\
\text { Sample }\end{array}$ & $\begin{array}{c}\text { Acreage } \\
\text { Posted }\end{array}$ & $\begin{array}{l}\text { Proportion of } \\
\text { All Land } \\
\text { in the } \\
\text { Sample }\end{array}$ \\
\hline $\begin{array}{l}\text { Berkeley } \ldots \ldots \ldots \\
\begin{array}{l}\text { Hampshire } \\
\text { Monroe }\end{array} \text {. } \ldots \ldots \ldots \ldots \\
\begin{array}{l}\text { Pendleton } \\
\text { Pocahontas }\end{array} \\
\begin{array}{l}\text { Preston } \\
\text { EASTERN REGION }\end{array}\end{array}$ & $\begin{array}{r}30 \\
45 \\
18 \\
40 \\
23 \\
43 \\
199\end{array}$ & $\begin{array}{c}\text { Per Cent } \\
39 \\
33 \\
17 \\
37 \\
25 \\
24 \\
29\end{array}$ & $\begin{array}{l}7,056 \\
43,619 \\
3,827 \\
17,671 \\
10,915 \\
15,484 \\
98,572\end{array}$ & $\begin{array}{l}\text { Per Cent } \\
37 \\
51 \\
20 \\
36 \\
30^{*} \\
29 \\
37\end{array}$ \\
\hline $\begin{array}{l}\text { Fayette } \ldots \ldots \ldots \\
\text { Lincoln } \\
\text { Wyoming } \\
\text { SOUTHERN REGION }\end{array}$ & $\begin{array}{r}13 \\
20 \\
3 \\
36\end{array}$ & $\begin{array}{r}27 \\
15 \\
9 \\
17\end{array}$ & $\begin{array}{r}19,374 \\
2,107 \\
6,049 \\
27,530\end{array}$ & $\begin{array}{r}11 \\
13 \\
3 \\
7\end{array}$ \\
\hline $\begin{array}{l}\text { Braxton } \\
\begin{array}{l}\text { Doddridge } \\
\text { Marshall } \\
\text { Roane }\end{array} \quad \ldots \ldots \ldots \ldots \ldots \\
\text { NORTHWESTERN } \\
\text { REGION } \ldots \ldots\end{array}$ & $\begin{array}{l}21 \\
25 \\
54 \\
40\end{array}$ & $\begin{array}{l}16 \\
27 \\
40 \\
27\end{array}$ & $\begin{array}{l}6,284 \\
3,618 \\
7,607 \\
6,608\end{array}$ & $\begin{array}{l}31 \\
22 \\
43 \\
26\end{array}$ \\
\hline Totals All Regions & $375^{* *}$ & $27 \approx$ & 150,219 & 21 \\
\hline
\end{tabular}

"Adjusted for one tract of 50,000 acres which, if included, would exaggerate the actual situation.

* If those who post only during hunting season are included, 399 owners or 29 per cent of all landowners post during the year.

more than 30 per cent of the landowners had their lands posted. Among regions the incidence of posting was highest in the Eastern region, 29 per cent, and lowest in the Southern region, 17 per cent. The proportion of landowners in the Northwestern region who had their lands posted (28 per cent) was almost as high as it was in the Eastern region.

In general, the survey results support the notion that posting is more important in the Eastern region of West Virginia. However, there are some exceptions. For instance, in the counties of Hampshire, Berkeley, and Pendleton, where crop and livestock enterprises are quite important, where there is considerable hunting pressure, and where the quality of land for hunting is relatively high, over a third of the landowners have their lands posted. At the same time it was found that 40 per cent of the landowners in Marshall County have their lands posted, and the hunting pressures in this county are not very strong, the quality of hunting lands is relatively poor, and the value of agricultural products sold is a third or less of the value of agricultural products sold in either Hampshire, Berkeley, or Pendleton counties. 


\section{Testing the Significance of Variations in the Proportions of Land Posted Among Counties and Regions}

Are these variations among counties and regions in the proportion of landowners who post statistically significant or simply reflections of chance error associated with the drawing of the random sample of landowners? To test these differences among counties and regions, chi-square tests were made under the following null hypotheses:

1. Among counties there is no difference in the proportion of landowners who post their lands.

2. Among regions there is no difference in the proportion of landowners who post their lands.

As shown in Tables 6 and 7 the results of these tests indicate that the differences among counties and among regions are much larger than would be expected on the basis of random error alone. Thus, it is concluded that the variations among counties and regions in the number of landowners who post their land are real differences.

\section{Relation Between Posting and Size of Landholding}

It was assumed that the posting of land would be positively related to size of land holding, i.e., the frequency of posting would be higher

\section{TABLE 6}

Chi-square tests of the differences among counties in the number of landowners who post their land, sample of West Virginia landowners, 1965

\begin{tabular}{|c|c|c|c|c|c|}
\hline \multirow[t]{2}{*}{ County } & \multicolumn{2}{|c|}{$\begin{array}{l}\text { Number of Landowners } \\
\text { With Posted Land }\end{array}$} & \multicolumn{2}{|c|}{$\begin{array}{c}\text { Number of Landowners } \\
\text { Who Do Not Post }\end{array}$} & \multirow[t]{2}{*}{$\begin{array}{c}\text { Total } \\
\text { Landowners }\end{array}$} \\
\hline & Actual & Theoretical & Actual & Theoretical & \\
\hline Berkeley & 30 & 21 & 46 & 55 & 76 \\
\hline Hampshire & 45 & 37 & 93 & 101 & 138 \\
\hline Monroe . & 18 & 29 & 89 & 78 & 107 \\
\hline Pendleton & 40 & 29 & 67 & 78 & 107 \\
\hline Pocahontas & 23 & 25 & 68 & 66 & 91 \\
\hline Preston & 43 & 47 & 131 & 127 & 174 \\
\hline Fayette & 13 & 13 & 35 & 35 & 48 \\
\hline Lincoln & 20 & 36 & 112 & 96 & 132 \\
\hline Wyoming & 3 & 9 & 30 & 24 & 33 \\
\hline Braxton & 21 & 36 & 113 & 98 & 134 \\
\hline Doddridge & 25 & 25 & 66 & 66 & 91 \\
\hline Marshall & 54 & 36 & 79 & 97 & 133 \\
\hline Roane & 40 & 40 & 108 & 108 & 148 \\
\hline Totals & $375(27 \%)$ & 383 & $1,037(73 \%)$ & 1,029 & 1,412 \\
\hline
\end{tabular}

Results of Chi-square test: Theoretical value of $\mathrm{X}^{2}$ (95 per cent level) with 12 degrees of freedom equals 21.026. The computed value of $\mathrm{X}^{2}$ equals 55.99. Therefore, the null hypothesis of no difference among counties is rejected. 
among landowners with large acreages than among landowners with small acreages.

As a first approximation the assumption can be tested by comparing the proportion of landowners who post with the proportion of all land in the sample that is posted. If posted lands are no larger or smaller than non-posted lands these proportions should be approximately equal. The data in Table 5 show that 27 per cent of all landowners have their lands posted but these same owners own 21 per cent of all land in the sample. On this basis, it would appear that landowners who post do not necessarily have larger land holdings.

However, among counties and regions there are noticeable exceptions to this aggregate situation. In Hampshire County, for example, 33

TABLE 7

Chi-square tests of the differences among regions in the number of landowners who post their land, sample of West Virginia landowners, 1965

\begin{tabular}{|c|c|c|c|c|c|}
\hline \multirow[b]{2}{*}{ Region } & \multicolumn{2}{|c|}{$\begin{array}{l}\text { Number of Landowners } \\
\text { With Posted Land }\end{array}$} & \multicolumn{2}{|c|}{$\begin{array}{l}\text { Number of Landowners } \\
\text { Who Do Not Post }\end{array}$} & \multirow{2}{*}{$\begin{array}{c}\text { Total } \\
\text { Landowner }\end{array}$} \\
\hline & Actual & Theoretical & Actual & Theoretical & \\
\hline Eastern & 199 & & 49 & & 693 \\
\hline & & & & & 213 \\
\hline Northwestern & 140 & 137 & 366 & 369 & 506 \\
\hline Totals & $375(2$ & 382 & $1,037(73 \%)$ & 1,030 & 1,412 \\
\hline
\end{tabular}

Results of Chi-square test: Theoretical value of $\mathrm{X}^{2}$ (95 per cent level) with two degrees of freedom equals 5.991. The computed value of $\mathrm{X}^{2}$ equals 12.61. Therefore, the null hypothesis of no difference among regions is rejected.

TABLE 8

\section{Chi-square test between size of landholding and posting, sample of West Virginia landowners, 1965}

\begin{tabular}{|c|c|c|c|c|c|}
\hline \multirow{2}{*}{$\begin{array}{l}\text { Acreage } \\
\text { Owned }\end{array}$} & \multicolumn{2}{|c|}{$\begin{array}{l}\text { Landowners With } \\
\text { Posted Land }\end{array}$} & \multicolumn{2}{|c|}{$\begin{array}{c}\text { Landowners Who } \\
\text { Do Not Post }\end{array}$} & \multirow{2}{*}{$\begin{array}{c}\text { Total } \\
\text { Landowners }\end{array}$} \\
\hline & Actual & Theoretical & Actual & Theoretical & \\
\hline 25-100 & 115 & 170 & 513 & 458 & 628 \\
\hline $101-200$ & 105 & 107 & 290 & 288 & 395 \\
\hline $201-300$ & 48 & 39 & 96 & 105 & 144 \\
\hline $301-400$ & 18 & 16 & 40 & 42 & 58 \\
\hline $401-500$ & 14 & 10 & 23 & 27 & 37 \\
\hline $501-1,000$ & 33 & 17 & 31 & 47 & 64 \\
\hline Over- 1,000 & 42 & 23 & 44 & 63 & 86 \\
\hline Totals & $375(27 \%)$ & 382 & $1,037(73 \%)$ & 1,030 & 1,412 \\
\hline
\end{tabular}

Results of Chi-square test: Theoretical value of $\mathrm{X}^{2}$ (95 per cent level) with six degrees of freedom equals 12.592. The computed value of $\mathrm{X}^{2}$ equals 71.72 . Therefore, the null hypothesis nf no difference in size of landholding and incidence of posting is rejected. 
per cent of the landowners have their lands posted, but these owners own 51 per cent of all land in the county that was included in the sample survey. A similar tendency is noted in Monroe, Pocahontas, Preston, Braxton, and Marshall counties. On the other hand there are counties where the reverse situation is noted. In Fayette County 27 per cent of the landowners post their land, but these lands account for only 11 per cent of all land sampled in Fayette County. The same tendency is noted in Lincoln, Doddridge, Berkeley, and Roane counties.

Among regions the same general trend is noted. In the Eastern region 29 per cent of the landowners have their lands posted but they own 37 per cent of all land in the region included in the sample. The situation is reversed in the Southern region where 17 per cent of the landowners post their land but own only 7 per cent of the sampled land.

These differences among counties and regions tend to offset each other and cover up the relationship between size of landholding and incidence of posting. For this reason a chi-square test was employed as a second approximation to the actual situation. The test was made under the null hypothesis of no difference between posting and size of landholding. The results of this test (Table 8 ) lead to a rejection of the null hypothesis, and the conclusion that there is a relationship between size of landholding and incidence of posting. The data show that landowners with larger acreages (500 acres and over) post more frequently and landowners with smaller acreages (less than 100 acres) less frequently than owners with landholdings between 100 and 500 acres. These results are consistent with those found in a Pennsylvania study where the extent of posting in three counties was 43,34 , and 52 per cent, yet those who posted owned 50,37 , and 70 per cent of the total land in the counties. ${ }^{11}$

\section{Relation of Posting to Hunter Damages}

It was assumed also that the frequency of postings would be related to property damage by hunters, i.e., if such damages had been incurred by a landowner, he would be more likely to post his lands than a landowner whose property had not been damaged. This assumption was tested by comparing the percentage of postings among those who had been damaged with the percentage of postings among those who had not been damaged by hunters.

The results of this test (Table 9 ) indicate that there is a tendency for landowners who have had their property damaged by hunters to post their lands more often than owners who have not been damaged. Approximately 46 per cent of those who suffered property damage by hunters posted their lands, whereas only 20 per cent of those who did not incur hunter damage posted their lands.

${ }^{11}$ Ibid., p. 10 . 


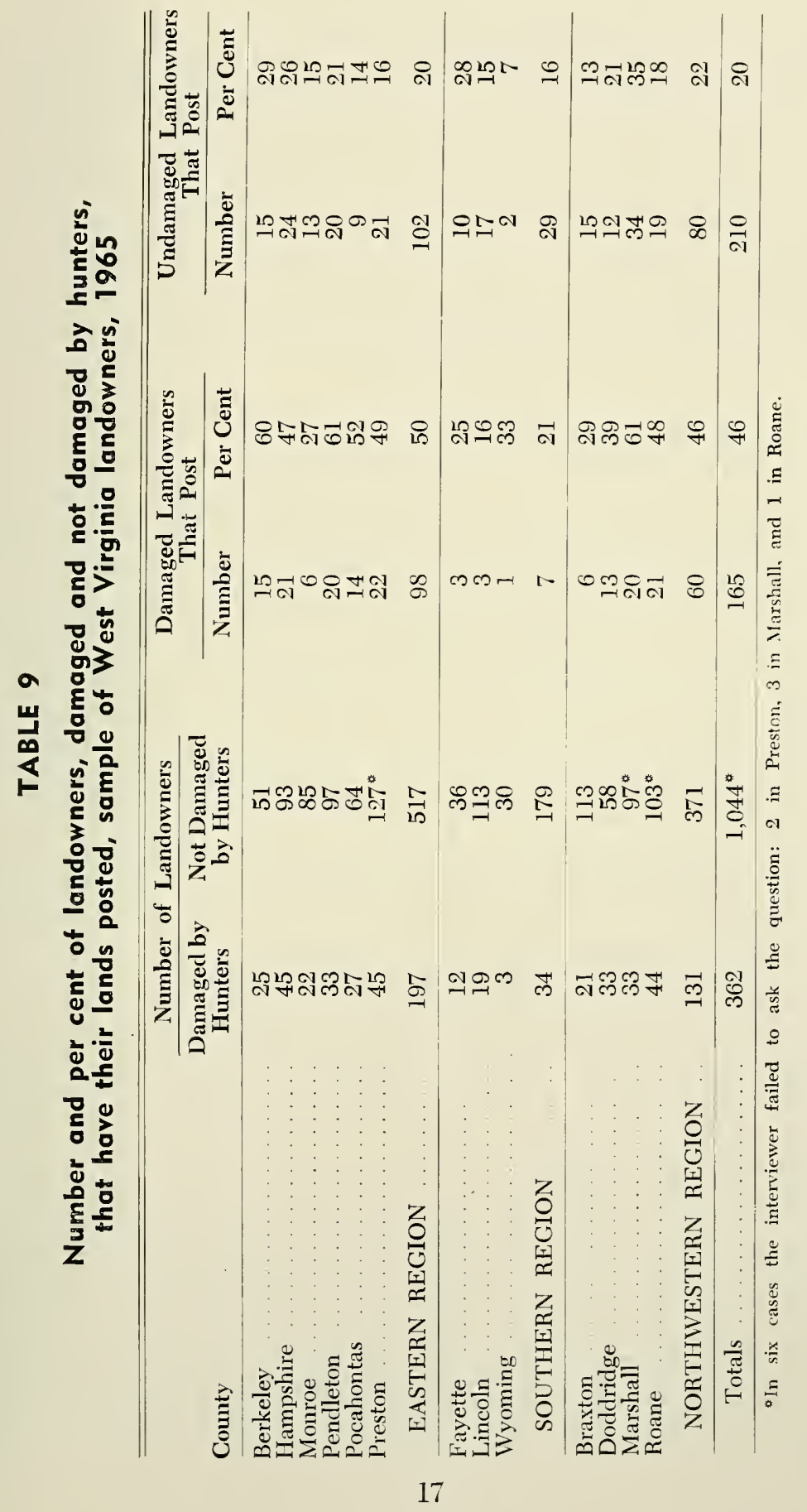




\section{Relation of Posting to Wildlife Damages}

It was presumed that frequency of posting and damage from wildlife would be inversely related, i.e., among those who suffer property damage from wildlife there would be a reluctance to diminish hunting by the erecting of posting signs. Thus, a comparison between the proportion of those damaged who post, and the proportion of those not damaged who post is presented in Table 10 . The results lend very little support to the assumption. In fact, the data show that posting occurs at a slightly higher frequency among those who have been damaged by wildlife. One might conclude that some landowners have a greater fear of hunter damage than wildlife damage.

\section{Posting Experience of Landowners Who Do Not Currently Have Their Land Posted}

Among the 73 per cent of landowners who did not have their lands under post at the time of the survey, slightly more than a fourth stated that they had posted their lands at some earlier period (Table 11). Over three-fourths of these owners who had previous experience with posting noted that they had maintained their posts for five years or less (Table 12). In fact, 40 per cent of these landowners had posted their lands for a period of one year or less.

Among landowners who did not have their lands posted at the time they were being interviewed but who had tried posting in earlier periods, the most important reasons given for discontinuing the posts were:

1. The signs rotted down, fell down, or were blown away.

2. The signs were torn down, burned down, or shot down by hunters.

3. The signs did not help; hunters hunted anyway.

4. Posting is done during hunting season only.

5. It took too much time and money to maintain the signs.

As indicated in Table 13 many other reasons were given but none of them were mentioned by a sizable number of landowners.

\section{Seasonal Posting of Land}

Each year the West Virginia Department of Natural Resources, Division of Game and Fish, conducts a series of public meetings in the major towns and cities of the State. At these hearings hunters, fishermen, hunting clubs, and other interested groups and individuals are invited to voice their opinions on such things as hunting and fishing regulations, seasons, game and fish programs, law enforcement procedures, stocking programs, etc. A common complaint which is registered at these meetings relates to those landowners who post their land just before the hunting 


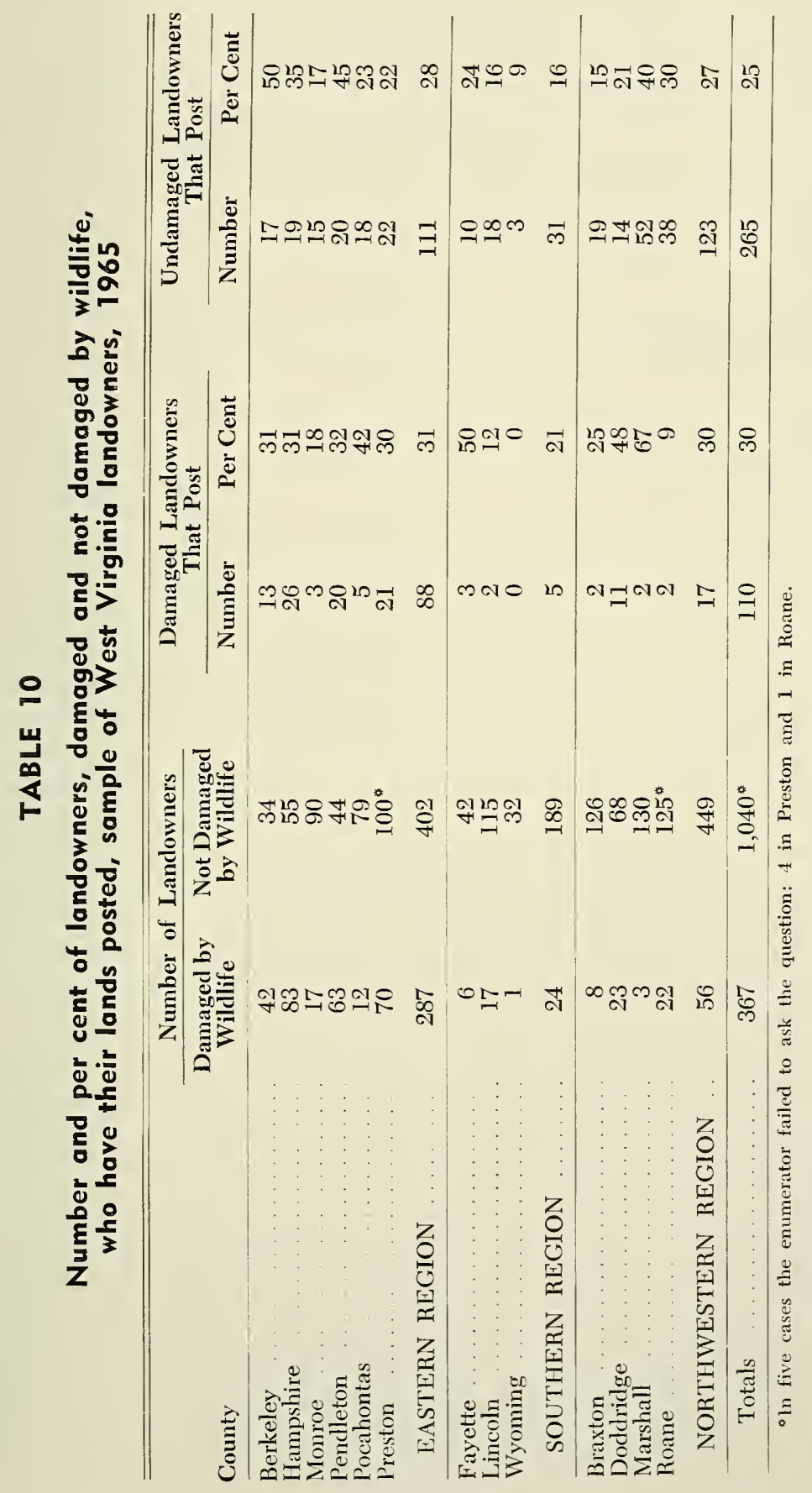




\section{TABLE 11}

Prior experience in posting of land among landowners whose lands are not currently posted, sample of West Virginia landowners, 1965

\begin{tabular}{|c|c|c|c|}
\hline County & $\begin{array}{l}\text { Have Posted } \\
\text { In the Past }\end{array}$ & $\begin{array}{l}\text { Have Not Posted } \\
\text { In the Past }\end{array}$ & $\begin{array}{c}\text { Not } \\
\text { Ascertained }\end{array}$ \\
\hline $\begin{array}{l}\text { Berkeley } \ldots \ldots \ldots \\
\begin{array}{l}\text { Hampshire } \\
\text { Monroe }\end{array} \text { Pendleton } \\
\text { Penahontas } \\
\text { Pocahon } \\
\text { Preston } \\
\text { EASTERN REGION }\end{array}$ & $\begin{array}{r}10 \\
35 \\
27 \\
6 \\
22 \\
39 \\
139\end{array}$ & $\begin{array}{r}36 \\
58 \\
60 \\
61 \\
46 \\
90 \\
351\end{array}$ & $\begin{array}{l}0 \\
0 \\
1 \\
0 \\
0 \\
1 \\
2\end{array}$ \\
\hline $\begin{array}{l}\text { Fayette } \ldots \ldots \ldots \ldots \ldots \\
\text { Lincoln } \\
\text { Wyoming } \\
\text { SOUTHERN REGION }\end{array}$ & $\begin{array}{r}11 \\
16 \\
4 \\
31\end{array}$ & $\begin{array}{r}24 \\
90 \\
26 \\
140 \\
\end{array}$ & $\begin{array}{l}0 \\
5 \\
0 \\
5\end{array}$ \\
\hline 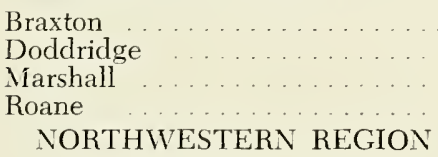 & $\begin{array}{r}17 \\
29 \\
21 \\
41 \\
108\end{array}$ & $\begin{array}{r}95 \\
37 \\
52 \\
67 \\
251\end{array}$ & $\begin{array}{l}1 \\
0 \\
4 \\
0 \\
5\end{array}$ \\
\hline Totals $\ldots \ldots \ldots$ & $278(27 \%)$ & $742(72 \%)$ & $12(1 \%)$ \\
\hline
\end{tabular}

season begins and subsequently remove their posting signs after the hunting season has officially closed. Apparently many hunters regard this act by landowners as unsportsmanlike conduct.

The results of the landowner survey do not support the contention that seasonal posting of land is an important phenomenon in West Virginia. As shown in Table 13, approximately 2 per cent of all respondents follow the practice of posting only during the hunting season. Furthermore, the 24 instances of intermittent posting are not concentrated in a few counties. Of the 24 landowners who practice seasonal posting, not more than four are located in a single county.

\section{Length of Current Post}

The widespread notion that the quantity of land under post has been increasing in recent years is adequately supported by information obtained from landowners (Table 14). Approximately 47 per cent of the current postings were established within the last five years. Further, twothirds of the current postings were made within the last ten years.

Again there is considerable variation among counties and among regions regarding the length of the current post. In Wyoming and Fayette counties, posting appears to be a relatively new phenomenon. All of the current postings have been made within the last ten years. Approximately three-fourths of the postings in Lincoln, Marshall, Pendleton, and Roane counties were made within the last ten years. On the other hand, 


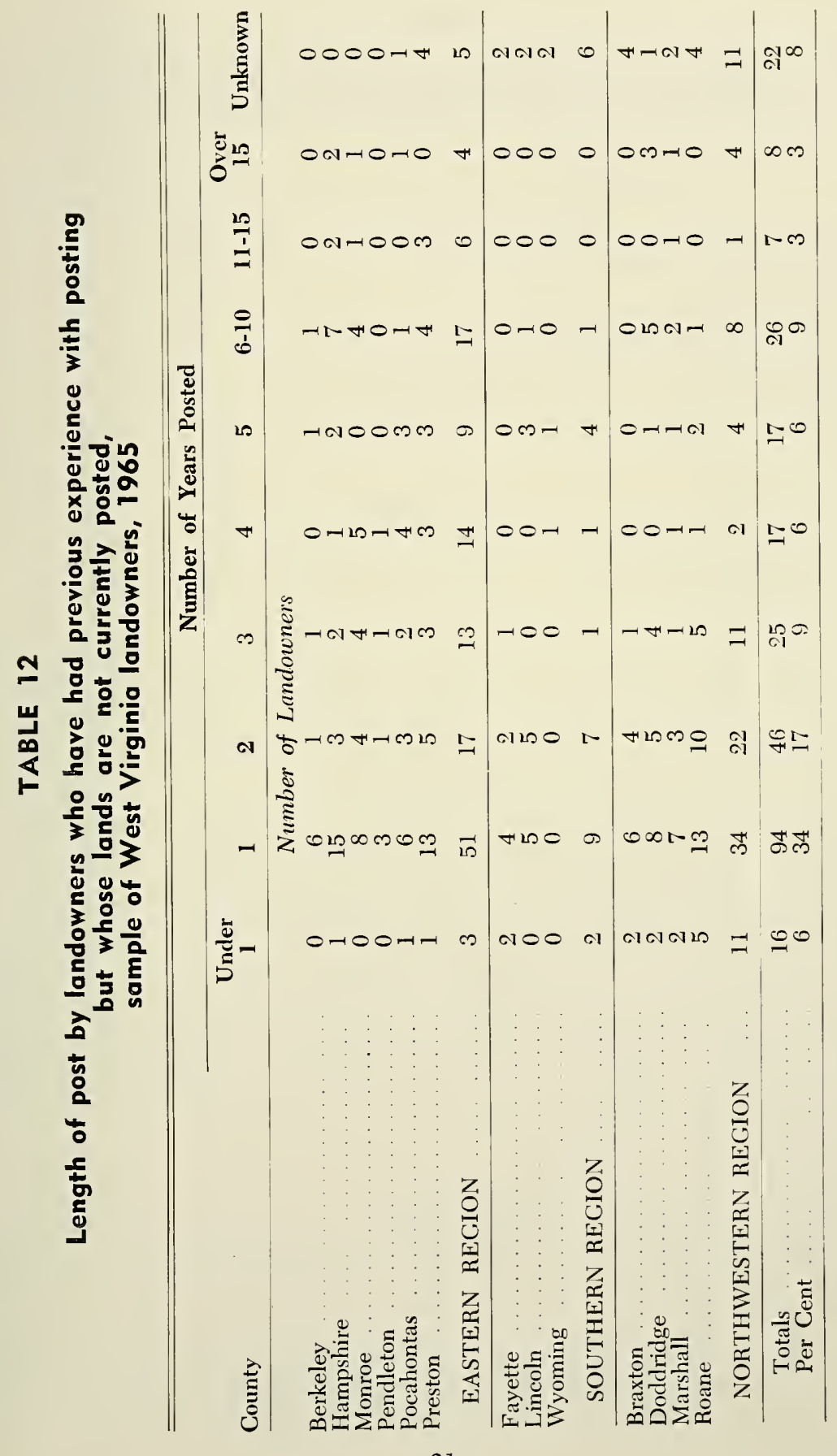


TABLE 13

Reasons given for discontinued postings by landowners who have had previous experience with posting but who do not currently have their lands posted, sample of West Virginia landowners, 1965

\begin{tabular}{|c|c|c|}
\hline \multirow[t]{2}{*}{ Reasons Given } & \multicolumn{2}{|c|}{ Landowners } \\
\hline & Number & Per Cent \\
\hline Weathered, rotted, fell down, blew down. & 64 & 23 \\
\hline Hunters tore them down, burned them, or & & \\
\hline shot them down $\ldots \ldots \ldots \ldots \ldots \ldots \ldots$ & 64 & 23 \\
\hline Didn't help; hunters hunted anyway ... & 47 & 17 \\
\hline Post during hunting season only ... & 24 & 9 \\
\hline Took too much time and money .......... & 17 & 6 \\
\hline Owner took them down; became "soft-hearted" & 10 & 4 \\
\hline Hunting club dissolved . . . . . . . . . . . . . & 8 & 3 \\
\hline Violations ceased, post removed & 8 & 3 \\
\hline Land is now fenced ........... & 8 & 3 \\
\hline People started fires. & 7 & 3 \\
\hline No game left $\ldots \ldots \ldots$ & 6 & 2 \\
\hline State imposed postings to build up the deer herd & 2 & 1 \\
\hline 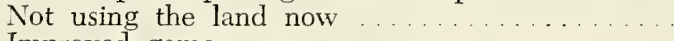 & 2 & 1 \\
\hline Improved game ............. & 1 & \% \\
\hline Needed help in case of fires & 1 & \% \\
\hline Quit raising livestock ....... & 1 & 。 \\
\hline Miscellaneous reasons & 10 & 4 \\
\hline No reasons given .... & 13 & 5 \\
\hline Total Landowners" & 278 & 100 \\
\hline
\end{tabular}

*Less than one-balf of 1 per cent.

* The total number of reasons is greater than the number of landowners with posted lands because some landowners gave more than one reason.

only 30 per cent of the postings in Berkeley and 50 per cent of those in Preston were made as recently as ten years ago.

Among the regions the data indicate that postings in the Southern and Northwestern regions have been made more recently than those in the Eastern region. Approximately one-fourth of the postings in the Eastern region have been maintained continuously for 16 years or over. Comparable percentage figures for the Southern and Northwestern regions are respectively, 3 and 13. These data indicate that, overall, landowners in the Eastern region have had longer experience in posting of land than landowners elsewhere in the State.

\section{Landowner Reasons for Posting of Land}

Why do landowners post their lands? As indicated in Table 15 the most important reasons given by those who presently have their lands posted are:

1. They want to restrict the total number of hunters and select among would-be users. This includes the refusing of access to anyone but family members, relatives, and close friends. 


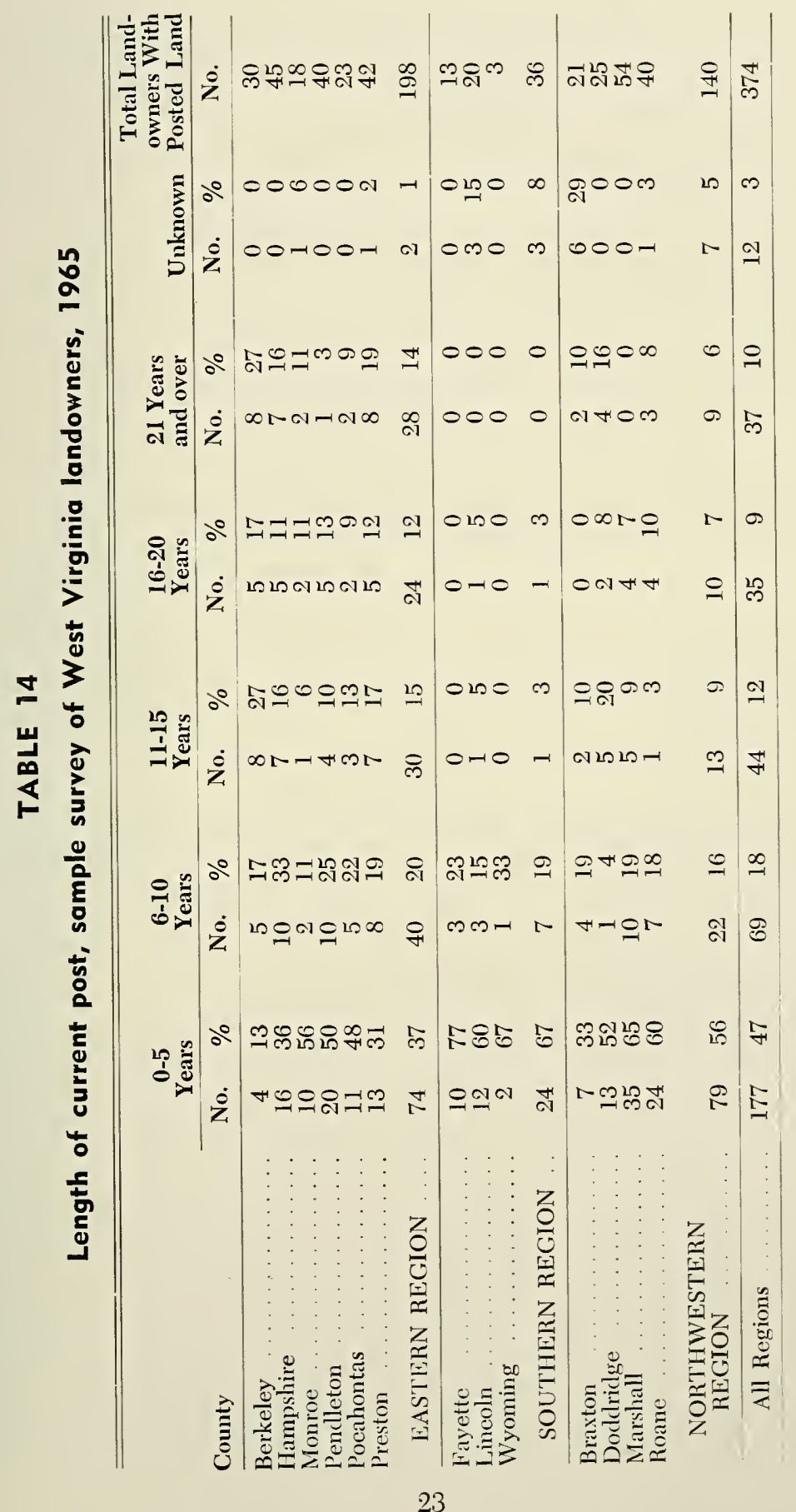


2. They fear that there will be damage done to their fences, buildings, livestock, or other property items. In addition, they are fearful of injuries to themselves or other persons and their personal liability for injuries.

3. They have actually suffered damages to livestock, fences, trees, and other property items.

4. They want to increase the supply of game on their lands.

5. They have leased their lands to hunting clubs who in turn made the postings.

6. They are retaliating against other landowners who post.

7. They simply prefer to keep everyone off their lands.

\section{TABLE 15}

\section{Reasons given for present postings of land, sample survey of West Virginia landowners, 1965}

\begin{tabular}{|c|c|c|}
\hline Reasons & Number & Per Cent \\
\hline $\begin{array}{l}\text { Restrictive and Selective Practices: } \\
\text { Restrict total number of hunters } \\
\text { Preserve the hunting for family, relatives, and friends } \\
\text { Keep hunters out } \\
\text { Keep strangers off } \\
\text { Make people ask permission to hunt } \ldots \ldots\end{array}$ & $\begin{array}{r}218 \\
79 \\
56 \\
34 \\
26 \\
23\end{array}$ & $\begin{array}{l}58 \\
(36) \\
(26) \\
(16) \\
(12) \\
(11)\end{array}$ \\
\hline $\begin{array}{l}\text { Fear of Damages to: } \\
\text { Property: unspecified property objects } \ldots \\
\text { Livestock } \\
\text { Persons, including hunters } \ldots \ldots\end{array}$ & $\begin{array}{r}127 \\
93 \\
21 \\
10 \\
3\end{array}$ & $\begin{array}{l}34 \\
(73) \\
(17) \\
(8) \\
(2)\end{array}$ \\
\hline $\begin{array}{l}\text { Actual Damages Incurred: } \\
\text { Property damaged or destroyed; unspecified } \\
\text { property objects } \\
\text { Livestock killed or injured } \\
\text { Fences damaged or destroyed } \\
\begin{array}{l}\text { Fires started } \ldots \\
\text { Livestock let out of pasture }\end{array} \\
\text { Livestock chased by hunters } \\
\text { Trees cut down }\end{array}$ & $\begin{array}{r}32 \\
20 \\
19 \\
6 \\
5 \\
3 \\
3\end{array}$ & $\begin{array}{l}(36) \\
(23) \\
(22) \\
(7) \\
(6) \\
(3) \\
(3)\end{array}$ \\
\hline $\begin{array}{l}\text { Improve the Game } \\
\text { Keep Everyone out } \\
\text { Fear of Liability for Injury to Hunters } \\
\text { Leased to Hunting Clubs . } \\
\text { Retaliation Against Others who Posted } \\
\text { Unstructured Reasons } \\
\text { No Reasons Given }\end{array}$ & $\begin{array}{r}30 \\
22 \\
8 \\
7 \\
5 \\
5 \\
16\end{array}$ & $\begin{array}{l}8 \\
6 \\
2 \\
2 \\
1 \\
1 \\
4\end{array}$ \\
\hline $\begin{array}{l}\text { Total Number of Landowners who have Their } \\
\text { Lands Posted }\end{array}$ & $374 *$ & 100 \\
\hline
\end{tabular}




\section{Attitudes and Opinions of Landowners Regarding Their Right to Post Land}

In an effort to gain better understanding of why landowners post their lands, the following two-part question was asked of all landowners in the sample. "Do you believe that landowners should have the right to post their lands?" Regardless of the answer to this question, each respondent was then asked "Why?"

As expected, practically all (96 per cent) of the owners answered yes to the original question (Table 16), and the follow-up question, "Why?" elicited the following ordering of attitudes:

1. Exertion of private property rights that accrue to owners of land.

2. Protection of person and property objects. This attitude arises from actual damages that have been incurred previously or from the fear of damages in a future period.

3. Selectivity among would-be hunters.

4. Control hunting pressure.

5. Conservation and protection of wildlife.

About three-fourths of all landowners believe that mere ownership of land, in itself, is sufficient reason for landowners to have the right of ex-

TABLE 16

\section{"Should landowners have the right to post their lands?" Responses from a sample of West Virginia landowners, 1965}

\begin{tabular}{|c|c|c|c|}
\hline County & Yes & No & No Answer \\
\hline $\begin{array}{l}\text { Berkeley } \\
\begin{array}{l}\text { Hampshire } \\
\text { Monroe } \\
\text { Pendleton } \\
\text { Pocahontas } \\
\text { Preston }\end{array} \quad \ldots \ldots \ldots \ldots \\
\end{array}$ & $\begin{array}{r}75 \\
134 \\
103 \\
103 \\
88 \\
170\end{array}$ & $\begin{array}{l}1 \\
4 \\
2 \\
4 \\
3 \\
2\end{array}$ & $\begin{array}{l}0 \\
0 \\
2 \\
0 \\
0 \\
2\end{array}$ \\
\hline EASTERN REGION & 673 & 16 & 4 \\
\hline $\begin{array}{l}\text { Fayette } \ldots \ldots \ldots \\
\text { Lincoln } \\
\text { Wyoming }\end{array}$ & $\begin{array}{r}48 \\
119 \\
30\end{array}$ & $\begin{array}{l}0 \\
7 \\
3\end{array}$ & $\begin{array}{l}0 \\
6 \\
0\end{array}$ \\
\hline SOUTHERN REGION & 197 & 10 & 6 \\
\hline 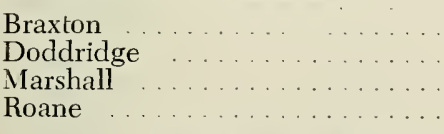 & $\begin{array}{r}128 \\
91 \\
124 \\
143\end{array}$ & $\begin{array}{l}5 \\
0 \\
6 \\
4\end{array}$ & $\begin{array}{l}1 \\
0 \\
3 \\
1\end{array}$ \\
\hline NORTHWESTERN REGION & 486 & 15 & 5 \\
\hline Total & $1,356(96 \%)$ & $41(3 \%)$ & $15(1 \%)$ \\
\hline
\end{tabular}


cluding others from land (Table 17). Protection of person or property objects was second in importance to landowners, followed by selectivity among hunters, control of hunting pressures, and finally conservation and protection of wildlife. It is ironic in a State where the overall quality of hunting is relatively low, that a larger number of landowners consider the right to post to be more important for selecting among hunters, than as an instrument which can be used for improving the quality of hunting on their lands.

It was noted earlier that posting signs do not necessarily imply that there is no hunting on the posted land. Many landowners use posting as a tool to restrict the total number of hunters and to allow them a degree of selectivity among would-be users. In many instances landowners prefer to restrict their lands for use by family members, relatives, and close friends. Posting is a means by which these preferences can be implemented.

Some of the expressions heard among owners such as "I want to know who is on the land," "I want them to ask permission," or "I want to keep those strangers and undesirables off," point out the role which these owners envision for posting. Legally, hunters are supposed to ob-

\section{TABLE 17}

\section{Reosons given by those landowners who believe that landowners should have the right to post their land, sample of West Virginia landowners, 1965}

\begin{tabular}{|c|c|c|}
\hline Reasons Given & $\begin{array}{l}\text { Number of } \\
\text { Landowners }\end{array}$ & $\begin{array}{l}\text { Proportion of } \\
\text { All Landowners }\end{array}$ \\
\hline $\begin{array}{l}\text { Exertion of Private Property Right } \ldots \ldots \\
\text { Their right under the law } \ldots \\
\text { I own the land } \\
\text { I own the land and pay taxes } \\
\text { To retain complete control of land } \ldots\end{array}$ & $\begin{array}{r}1,046 \\
228 \\
421 \\
328 \\
69\end{array}$ & $\begin{array}{r}74 \\
(22) \\
\left(\begin{array}{r}40) \\
31 \\
7\end{array}\right)\end{array}$ \\
\hline $\begin{array}{l}\text { Protection of Person and Property Objects } \\
\text { Protect myself and family } \\
\text { To protect my property } \ldots \ldots \\
\text { To protect stock }\end{array}$ & $\begin{array}{r}431 \\
20 \\
386 \\
25\end{array}$ & $\left(\begin{array}{r}31 \\
5\end{array}\right)$ \\
\hline $\begin{array}{l}\text { Selectivity Among Would Be Hunters } \\
\text { Keep undesirable people off, including } \\
\text { strangers ................... } \\
\text { Likes to know who is on the land }\end{array}$ & $\begin{array}{l}97 \\
31\end{array}$ & $\begin{array}{r}9 \\
\left(\begin{array}{r}76) \\
24)\end{array}\right.\end{array}$ \\
\hline $\begin{array}{l}\text { Control Hunting Pressure } \ldots \ldots \ldots \ldots \\
\text { Control the number of hunters } \ldots \ldots \ldots\end{array}$ & $\begin{array}{l}76 \\
76\end{array}$ & $\begin{array}{c}5 \\
(100)\end{array}$ \\
\hline 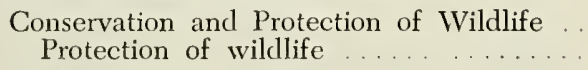 & $\begin{array}{l}59 \\
59\end{array}$ & $\begin{array}{c}4 \\
(100)\end{array}$ \\
\hline To Make Hunters Ask Permission ...... & 11 & 1 \\
\hline Miscellaneous Reasons ........ & 26 & 2 \\
\hline No Reason Given ..... & 101 & 7 \\
\hline
\end{tabular}


tain permission to hunt on another's land, but tradition and custom rules against the legal code in many instances. Posting signs, however, serve in the role of silent policemen, and seemingly, most hunters refrain from using lands that are so marked unless permission is granted by the landowner. Thus, posting tends to reinforce the legal code and assists in the channeling of would-be users to the landowner's door at which time he can choose to let them hunt or not hunt upon his land, and decide whether he will ask an admittance fee or allow free hunting.

\section{Discrimination Among Hunters by West Virginia Landowners}

How selective, or restrictive, are West Virginia landowners, especially those who post, among would-be hunters on their land? The results of the landowner survey indicate that 92 per cent of those who currently have their lands posted permit some hunting (Table 18). However, a large majority of these landowners practice a degree of selectivity among hunters. Approximately 14 per cent allow anyone to hunt upon their land and 78 per cent select among would-be users. Among those who follow a discriminatory policy, 70 per cent allow hunting only by family members, relatives, and close friends. In addition, another 9 per cent restrict hunting to their family only or to their family and relatives. Approximately 3 per cent post their lands for exclusive use by hunting club members.

To what extent do these restrictive and discriminatory policies of landowners who have their lands posted differ from the policies of those who do not post? The data in Table 19 strongly suggest that landowners who post are more selective among users than owners who do not post. Among landowners who do not post, 73 per cent permit anyone to hunt on their lands. In comparison, only 14 per cent of those who post allow anyone who so desires to hunt on their land. Twenty-four per cent of the landowners who do not post discriminate among hunters, but of those who post 78 per cent select among hunters. Among landowners who do not post, but who practice selection of hunters on their land, 86 per cent allow only family members, relatives, and close friends to hunt. In comparison only 70 per cent of those who post allow family members, relatives, and close friends to bunt. Finally, 4 per cent of those who do not post prohibit hunting by anyone, compared to 8 per cent of those who post their land.

The data also show that a majority of landowners who are obtaining income from hunting have their lands posted. Approximately 17 per ceni of those who post allow club members and fee paying guests to hunt on their lands. In comparison only 1 per cent of those who do not post have similar arrangements with club members and fee-paying guests. 


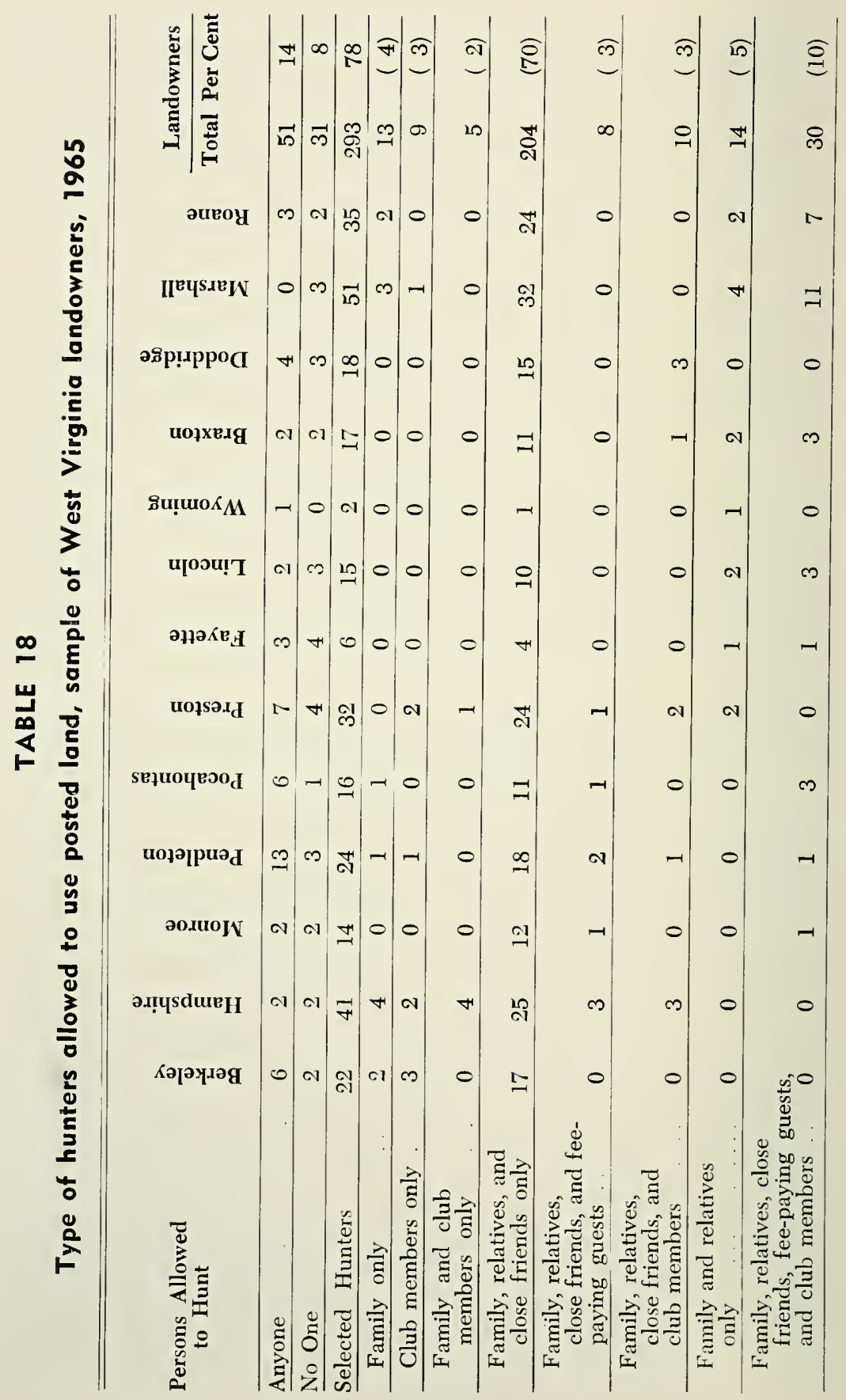


TABLE 19

Members of the hunting public that are allowed to hunt on posted and non-posted lands, sample of West Virginia landowners, 1965

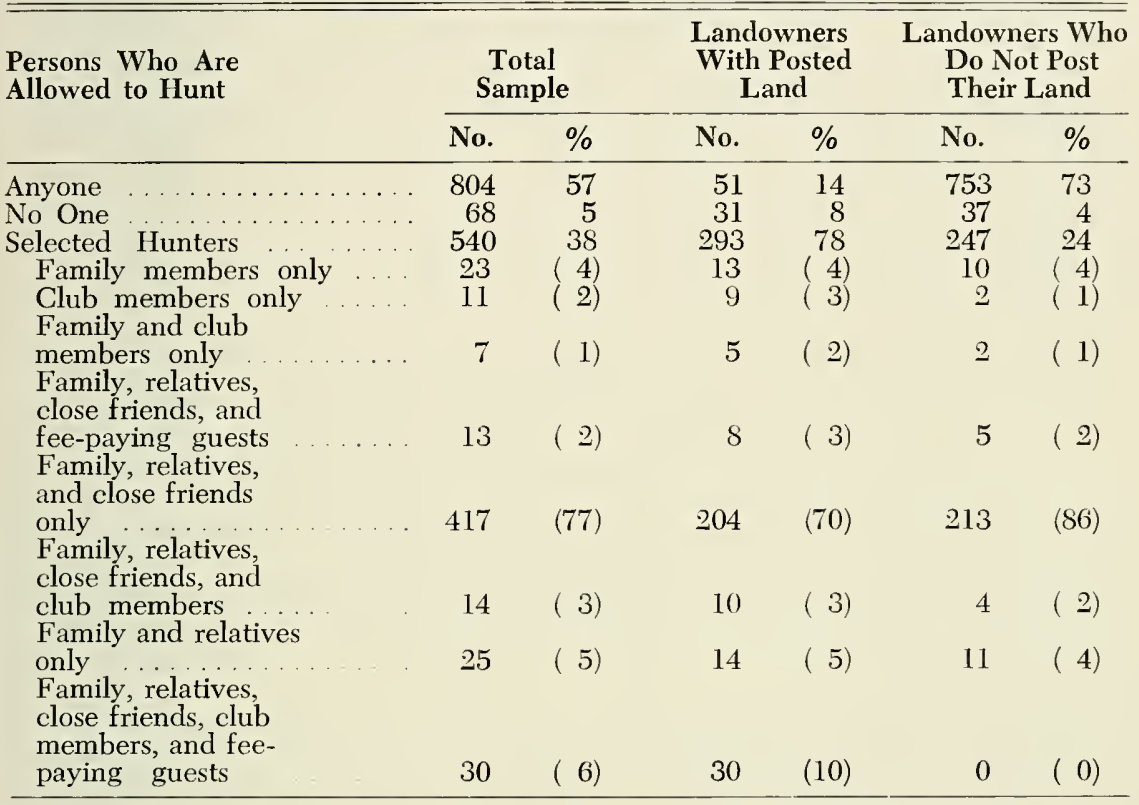

\section{Admission Requirements to Hunt on Privately Owned Lands}

In view of the large proportion of landowners who allow family members, relatives and close friends to hunt on their lands, and the small proportion of owners that assess fees on individual hunters or have contractual arrangements with hunting clubs, it is not surprising that the terms of entry are largely non-price requirements (Table 20). Approximately 43 per cent of all landowners allow hunters to use their lands without even asking permission, 39 per cent require oral permission, 3 per cent require written permission, 9 per cent require either oral or written permission, and approximately 1 per cent require club membership. Altogether, 91 per cent of all landowners in the sample allow hunting on their lands with no greater entrance cost than simply obtaining oral permission from the landowner.

A comparison of entry terms between landowners who post their lands and those who do not post shows that those who post tend to be a little more stringent in their entry requirements (Table 20). Among those who post, 22 per cent allow hunters to use their lands without asking, whereas 51 per cent of those who do not post allow hunting without being asked. At the same time 58 per cent of those who post require 
TABLE 20

Terms of entry on posted and non-posted land, sample of West Virginia landowners, 1965

\begin{tabular}{|c|c|c|c|c|c|c|}
\hline \multirow[t]{2}{*}{$\begin{array}{c}\text { Type } \\
\text { Requirement }\end{array}$} & \multicolumn{2}{|c|}{$\begin{array}{c}\text { Total } \\
\text { Sample }\end{array}$} & \multicolumn{2}{|c|}{$\begin{array}{l}\text { Landowners } \\
\text { Who Post }\end{array}$} & \multicolumn{2}{|c|}{$\begin{array}{l}\text { Landowners } \\
\text { Who Do Not Post }\end{array}$} \\
\hline & No. & $\%$ & No. & $\%$ & No. & $\%$ \\
\hline Without Asking . . . . & 609 & 43 & 82 & 22 & 527 & 51 \\
\hline Oral Permission Only & 554 & 39 & 174 & 46 & 380 & 37 \\
\hline Written Permission Only & 37 & 3 & 31 & 8 & 6 & 1 \\
\hline Written or Oral & & & & & & \\
\hline $\begin{array}{l}\text { Permission Only } \\
\text { Club Members Only }\end{array}$ & 130 & 9 & 45 & 12 & 85 & 8 \\
\hline Fee-Paying Guests & & 1 & 0 & & & \\
\hline Only & 3 & * & 2 & 1 & 1 & * \\
\hline $\begin{array}{l}\text { No One Allowed } \\
\text { To Hunt ... }\end{array}$ & 68 & 5 & 35 & 9 & 33 & 3 \\
\hline Totals & 1,412 & 100 & 375 & 100 & 1,037 & 100 \\
\hline
\end{tabular}

${ }^{*}$ Less than one-half of 1 per cent.

at least oral permission compared to 45 per cent of those who do not post. Written permission is required by $\delta$ per cent of those who post and 1 per cent of those who do not post. Finally, 9 per cent of those who post deny access to anyone compared to 3 per cent of those who do not post.

\section{Legal Provisions for Excluding Hunters on Privately Cwned Land}

\section{The provisions of the IVest Virginia Legal Code state that:}

It shall be unlawful for any person to shoot, hunt, fish, or trap upon the fenced, enclosed or posted grounds or lands of another person or to peel trees or timber, build fires or do any other act or thing thereon in connection with or auxiliary to shooting, hunting, fishing, or trapping on such lands without permission in writing from the owner, tenant or agent of such owner, and every person hunting, fishing, shooting, or fowling upon such lands shall have in his possession such written permission when so doing.

Any person who, for the purpose of, or while hunting, trapping, or fishing, shall, without the permission of the owner, tenant or agent of the owner, enter upon the land of another . . . shall be guilty of a misdemeanor and, in addition shall be liable to the owner for all damages and costs resulting therefrom.

The officers charged with the enforcement of the provisions of this chapter shall have the duty to enforce the provisions of this section if requested to do so by such owner, lessee, person or agent, but not otherwise. $^{12}$

As noted in the Code it is illegal to hunt upon the fenced or posted lands of another person without his written permission to do so. However, considerable hunting is done on privately owned land, fenced or not fenced, without obtaining written or oral permission from the landowner. Customs and old habits are slow to change and a common practice of many hunters is to hunt anywhere so long as the land is not posted with "no trespassing" or "no hunting" signs.

12West Virginia Code of 1961, Vol. 1, annotated, Chapter 20, Article 2, Part 1, Section 2225 (Charlottesville: The Mitchie Company, 1961), p. 1239. 
As noted above, Chapter 20 of the Code refers to the fenced land of another person without specifying what constitutes a fence. In Chapter 19 of the Code the definition of a lawful fence is stated as follows:

Every fence of the height and description hereinafter mentioned shall

be deemed a lawful fence ... that is to say:

a) If built with common rails, known as worm fence, four and one-half feet high;

b) If built with posts and rails, or posts and plank, or pickets, four feet high;

c) If built with stone, two feet wide at base, and three and one-half feet high:

d) If a hedge fence, four feet high. If any hedge fence be built upon a mound, the same from the bottom of the ditch shall be included in estimating the height of such fence;

e) If built with posts and wire, or pickets and wire, four feet high, and shall consist of not less than six strands, the first strand 5 inches, the second strand 10 inches, the third strand 17 inches, the fourth strand 25 inches, the fifth strand 36 inches, and the sixth strand 48 inches from the ground; and if with more than six strands, the space between the strands shall in no case be greater than hereinbefore provided. The space between the posts shall, in no case, be greater than 16 feet. $^{13}$

These provisions of a lawful fence are so exacting that it is unlikely that many fences in the State would qualify as lawful fences. As a result, it is assumed that the reference to fenced lands in Chapter 20 means any kind of fence, regardless of whether it does or does not meet the definition of a lawful fence. Professor Londo H. Brown, College of Law, WVest Virginia University, made the same interpretation of these two laws. ${ }^{14}$

Thus, it appears that fencing constitutes a legal post of land, and that written permission is required to legally hunt on land that is fenced or posted. The Code is silent with respect to land that is neither fenced nor posted. However, if one traverses over the land of another and does damage to his property or person, the owner can instigate civil court proceedings under the common laws of trespassing.

The posting laws of West Virginia are rather general and provide no exact specifications for landowners who desire to post their lands. These laws refer only to unenclosed lands thereby supporting the assumption that any type or kind of fence constitutes a legal post of land. According to the posting law:

The owner, lessee or other person entitled to possession of unenclosed lands may have erected and maintained signs or placards legibly printed, easily discernible, conspicuously posted and reasonably spaced, so as to indicate the territory in which hunting, trapping or fishing is prohibited. Any person who enters upon the unenclosed lands of another which have been lawfully posted, for the purpose of hunting, trapping, or fishing, shall be guilty of a misdemeanor. The officers charged with the enforcement of the provisions of this chapter shall have the duty to enforce the provisions of this section if requested to do so by such owner, lessee, person, or agent, but not otherwise. ${ }^{15}$

${ }^{13}$ Ibid., Chapter 19, Article 17, p. 1182.

${ }_{14}$ Telephone conversation between the writer and Professor Londo H. Brown, West Virginia University; on November 15, 1965.

15West Virginia Code of 1961, Vol, 1, annotated, Chapter 20, Article 2, Part 1, Section 2226 (Charlottesville: The Mitchie Company, 1961), p. 1240. 
The law is silent with regard to exact number of feet between signs, specific lettering size, height from ground level, etc. In spite of this lack of specificity, it is illegal to trespass on posted lands without the owner's permission. Each month the State Department of Natural Resources publishes a list of prosecutions for violations of their provisions, and the normal fine imposed upon those who do not obtain the owner's permission prior to hunting on his land is $\$ 20.00 .^{16}$

Thus, the legal Code of West Virginia details explicitly the right of landowners to exclude others from their land. Furthermore, the procedure for enforcing this right to exclude is outlined in each of the Codes. Any landowner who desires to exclude the hunting public from his land can expect assistance, if necessary, from certain public officials. In each of the 55 counties there is a sheriff and one or more conservation officers whom landowners can contact if they wish to prosecute hunters who cross fences, or disregard posting signs without obtaining permission to do so.

\section{Unwritten Rules and Values that Influence Landowner Decisions to Allow Public Hunting on Privately Owned Lands}

In spite of the legal Codes, landowners are influenced, in large measure, by the prevailing attitudes and social values in the communities where they live. Traditionally, hunting has been considered as something akin to a God-given right that everyone possesses. According to custom, everyone has the right to hunt and there should be land on which this right can be exercised. Furthermore, since the wildlife belongs to everyone, landowners should not assess entry fees or other charges on those who wish to hunt.

Landowner attitudes of these traditional values and customs have no small influence on the income potential that might be derived from hunting on privately owned land. If a majority of private owners still believe and adhere to these traditional views, the conversion of what has been a free service (free entry) into private income by selling or leasing hunting rights, or charging of access fees, will be seriously jeopardized. To appraise this aspect of the hunting situation in West Virginia a series of questions was asked of each respondent in the sample survey of landowners. Especially, these survey questions were used to solicit information that would be useful in answering the following questions:

1. Among private landowners, how widespread is the traditional view that lands should be open and free for hunting?

2. Is there any evidence that the older customs and values are being replaced by newer ones?

16West Virginia Conscrvation, Vol. XXIX, Nos. 4, 5, and 6 (Charleston: West Virginia Department of Natural Resources, 1965), pp. 29-32, and 23-25. 
3. What are the prevailing attitudes among private landowners about the assessment of fees on those who wish to use their lands for hunting?

\section{Marketing of Hunting Rights in West Virginia (Sample Survey Results)}

All landowners in the survey were asked, "Do you rent or lease hunting rights on your land?" Out of 1,412 landowners in 13 counties only 17 , or one per cent, indicated that they were currently leasing hunting rights on their land (Table 21). Among these 17 owners, 15 had their lands leased to hunting clubs and 2 had entered leasing arrangements with private individuals. Further, 15 of these 17 landowners were located in the Eastern region of IVest Virginia. Five cases were found in Hampshire County, 4 in Berkeley, 3 in Pocahontas, 2 in Preston, and 1 each in Pendleton, Marshall, and Wyoming counties.

The data point out rather clearly that at the present time only a small proportion ( 1 per cent) of West Virginia landowners are realizing an income from the sale of hunting rights on their land. Further, almost all of the landowners who do sell hunting rights are located in the Eastern region where the overall hunting quality is superior to that in the Southern or Northwestern regions.

\section{Attitudes of Landowners on the Assessment of Hunting Fees}

As noted in Table 22, a large proportion (70 per cent) of all landowners in the sample do not believe that charges should be levied on

TABLE 21

\section{Frequency of leased hunting rights, by county, sample of West Virginia landowners, 1965}

\begin{tabular}{|c|c|c|c|c|}
\hline \multirow[t]{2}{*}{ County } & \multicolumn{2}{|c|}{$\begin{array}{l}\text { Landowners Who } \\
\text { Lease Hunting Rights }\end{array}$} & \multicolumn{2}{|c|}{$\begin{array}{l}\text { Landowners Who Do } \\
\text { Not Lease Hunting Rights }\end{array}$} \\
\hline & Number & Per Cent & Number & Per Cent \\
\hline Berkeley . & 4 & 5 & 72 & 95 \\
\hline Hampshire & 5 & 4 & 133 & 96 \\
\hline Monroe & 0 & 0 & 107 & 100 \\
\hline Pendleton & 1 & 1 & 106 & 99 \\
\hline Pocahontas & 3 & 3 & 88 & 97 \\
\hline Preston ... & 2 & 1 & 172 & 99 \\
\hline Fayette & $\overline{0}$ & 0 & 48 & 100 \\
\hline Lincoln & 0 & 0 & 132 & 100 \\
\hline Wyoming & 1 & 3 & 32 & 97 \\
\hline Braxton & 0 & 0 & 134 & 100 \\
\hline Doddridge & 0 & 0 & 91 & 100 \\
\hline Marshall & 1 & 1 & 132 & 99 \\
\hline Roane . & 0 & 0 & 148 & 100 \\
\hline Totals & 17 & 1 & 1,395 & 99 \\
\hline
\end{tabular}


TABLE 22

\section{Landowner opinions on the assessment of hunting fees, sample survey of West Virginia landowners, 1965}

\begin{tabular}{|c|c|c|c|c|c|c|}
\hline \multirow[b]{2}{*}{ County } & \multicolumn{2}{|c|}{$\begin{array}{c}\text { Those Believing } \\
\text { That Fees Should } \\
\text { Be Charged }\end{array}$} & \multicolumn{2}{|c|}{$\begin{array}{l}\text { Those Believing } \\
\text { That Fees Should } \\
\text { Not Be Charged }\end{array}$} & \multirow{2}{*}{\multicolumn{2}{|c|}{$\begin{array}{c}\text { No Opinion } \\
\text { Number Per Cent }\end{array}$}} \\
\hline & Number & Per Cent & Number & Per Cent & & \\
\hline $\begin{array}{l}\text { Berkeley .... } \\
\text { Hampshire } \\
\text { Monroe } \\
\text { Pendleton } \\
\begin{array}{l}\text { Pocahontas } \\
\text { Preston }\end{array} \\
\end{array}$ & $\begin{array}{l}12 \\
59 \\
38 \\
42 \\
29 \\
75\end{array}$ & $\begin{array}{l}16 \\
43 \\
36 \\
39 \\
32 \\
43\end{array}$ & $\begin{array}{l}62 \\
77 \\
61 \\
65 \\
60 \\
94\end{array}$ & $\begin{array}{l}82 \\
56 \\
57 \\
61 \\
66 \\
54\end{array}$ & $\begin{array}{l}2 \\
2 \\
8 \\
2 \\
5\end{array}$ & $\begin{array}{l}3 \\
1 \\
7 \\
2 \\
2 \\
3\end{array}$ \\
\hline $\begin{array}{l}\text { EASTERN } \\
\text { REGION }\end{array}$ & 255 & 37 & 419 & 60 & 19 & 3 \\
\hline $\begin{array}{l}\text { Fayette } \\
\text { Lincoln } \\
\text { Wyoming }\end{array}$ & $\begin{array}{r}11 \\
15 \\
5\end{array}$ & $\begin{array}{l}23 \\
11 \\
15\end{array}$ & $\begin{array}{r}35 \\
107 \\
27\end{array}$ & $\begin{array}{l}73 \\
81 \\
82\end{array}$ & $\begin{array}{r}2 \\
10 \\
1\end{array}$ & $\begin{array}{l}4 \\
8 \\
3\end{array}$ \\
\hline $\begin{array}{l}\text { SOUTHERN } \\
\text { REGION }\end{array}$ & 31 & 15 & 169 & 79 & 13 & 6 \\
\hline $\begin{array}{l}\text { Braxton } \ldots \ldots \ldots \ldots \\
\text { Doddridge } \ldots \ldots \ldots \ldots \\
\text { Marshall } \ldots \ldots \ldots \ldots \\
\text { Roane } \ldots \ldots \ldots \ldots\end{array}$ & $\begin{array}{l}17 \\
19 \\
21 \\
36\end{array}$ & $\begin{array}{l}13 \\
21 \\
16 \\
24\end{array}$ & $\begin{array}{r}114 \\
72 \\
107 \\
107\end{array}$ & $\begin{array}{l}85 \\
79 \\
80 \\
72\end{array}$ & $\begin{array}{r}3 \\
\times 5 \\
5\end{array}$ & $\begin{array}{l}2 \\
4 \\
3\end{array}$ \\
\hline $\begin{array}{l}\text { NORTHWESTERN } \\
\text { REGION } \ldots . . .\end{array}$ & 93 & 18 & 400 & 79 & 13 & 3 \\
\hline All Regions & 379 & 27 & 988 & 70 & 45 & 3 \\
\hline
\end{tabular}

hunters. Although this view is held by a majority of owners in each region, there is a difference in the magnitude of the majority among regions. In the Southern and Northwestern regions approximately $S 0$ per cent of the landowners do not believe in charging hunting fees. In contrast, only 60 per cent of the owners in the Eastern region are opposed to hunting fees. It is significant to note that in the region where there is relatively less opposition to hunting fees there is a majority of landowners who are currently obtaining income from the sale of hunting rights. Further, it is in this region that relatively higher quality hunting lands and generally lower population densities are noted.

\section{Reasons for Opposition to Hunting Fees}

Why do West Virginia landowners oppose hunting fees? As noted in Table 23, there are many reasons for such opposition but those which are mentioned with greatest frequency are those which support traditional values such as "game belongs to everyone," "everyone's right to 


\section{Landowner reasons for opposition to hunting fees, sample of West Virginia landowners, 1965}

\begin{tabular}{|c|c|c|}
\hline \multirow[b]{2}{*}{ Reasons Given } & \multicolumn{2}{|c|}{ Landowners } \\
\hline & Number & Per Cent \\
\hline Game belongs to everyone $\ldots \ldots \ldots \ldots \ldots$ & 127 & 13 \\
\hline Everyone's right; free country, free hunting & 56 & 6 \\
\hline Never did charge $\ldots \ldots \ldots \ldots \ldots \ldots$ & 34 & 3 \\
\hline Not a sport to charge $\ldots \ldots \ldots \ldots$ & 27 & 3 \\
\hline Enjoys letting everyone hunt $\ldots \ldots \ldots$ & 25 & 3 \\
\hline Should allow no hunting if charges must be made & 19 & 2 \\
\hline 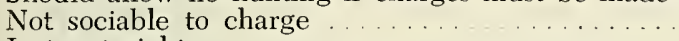 & 13 & 1 \\
\hline Just not right $\ldots \ldots$ & 89 & 9 \\
\hline Does not desire to charge friends and neighbors & 70 & 7 \\
\hline Not fair to charge after a license is bought & 17 & 2 \\
\hline If people pay, must guarantee something & 7 & 1 \\
\hline Would have to charge everyone & 4 & : \\
\hline Would accept a fee if offered.. & 5 & 1 \\
\hline No desire to pay themselves $\ldots$ & 88 & 9 \\
\hline Unless money invested in wildlife & 23 & 2 \\
\hline As long as no property damage . & 65 & 7 \\
\hline As long as number of hunters can be restricted & 17 & 2 \\
\hline Require oral permission only $\ldots \ldots \ldots \ldots$ & 20 & 2 \\
\hline Not enough game $\ldots \ldots \ldots$ & 67 & 7 \\
\hline Miscellaneous reasons & 157 & 16 \\
\hline No reason . r....... & 158 & 16 \\
\hline * Total Landowners Opposed to Hunting Fees & 988 & 100 \\
\hline
\end{tabular}

${ }^{\circ}$ Less than one-half of 1 per cent.

* The total number of reasons is greater than the number of landowners because some landowners gave more than one reason.

hunt," "not sporting or sociable to charge," and simply "it's not right to charge."

Actually the stated reasons for opposing hunting fees follow a rather clear pattern. First, there is a large reservoir of opinion and attitudes that supports the traditional custom of open and free hunting lands. Second, among landowners these attitudes are not held with the same degree of intensity. Some landowners qualify their attitude against fees by noting that they do not desire to charge friends and neighbors, while other landowners feel it is not fair to charge hunters after they purchase a license. Thus, some owners might be tempted to charge if they could, in good conscience, do it in a discriminatory manner. Five landowners would be so tempted that fees would be accepted if offered by hunters.

Third, the fear of being charged themselves is the qualifying reason that was given by 9 per cent of those owners who are opposed to hunting fees. It is likely that this group of landowners would not be opposed to fees if they did not go hunting.

Fourth, although generally against hunting fees, there is a group of landowners who would make exceptions if a clear case of equity were 
involved. These owners stated that charges would be equitable if the landowners actually incurred costs from the stocking of wildlife, or otherwise provided a more desirable habitat for game animals, or if the landowner actually suffered property damages from hunters.

Fifth, a few owners qualified their opposition to fees by stating that fees are not necessary so long as the number of hunters can be restricted by using other means. In this connection, a few owners noted that they require oral permission only, a process which, if enforced, can be used to control hunting pressure.

Sixth, and last, about 7 per cent of the landowners who oppose hunting fees indicated that their opposition stems from the lack of game. Significantly, most of the landowners voicing this opinion were located in counties of the Southern and Northwestern regions where the overall quality of hunting lands for most wildlife is relatively poor.

\section{Reasons for Favoring Hunting Fees}

In spite of the large number of qualifying reasons that were given by landowners who favor hunting fees, their attitudes or opinions can be generally categorized in three groups (Table 24). First, there is a group that favors fees so long as they can be assessed in a discriminatory fashion. Among these owners some would like to charge strangers, city

\section{TABLE 24}

\section{Landowner reasons for favoring hunting fees, sample of West Virginia landowners, 1965}

\begin{tabular}{|c|c|c|}
\hline \multirow[b]{2}{*}{ Reasons Given } & \multicolumn{2}{|c|}{ Landowners } \\
\hline & Number & Per Cent \\
\hline Depends on the individual or group that asks to hunt & 7 & 2 \\
\hline If not his friends or neighbors $\ldots \ldots \ldots$ & 7 & $\overline{2}$ \\
\hline If strangers, city folks, or hunting clubs. & 29 & 8 \\
\hline 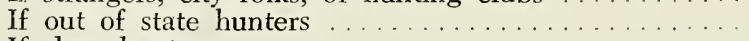 & 5 & 1 \\
\hline If deer hunters ...... & 1 & $\bar{\Delta}$ \\
\hline Know who is hunting ......... & 3 & 1 \\
\hline Restrict the number that hunts ... & 20 & 5 \\
\hline Would not cause as much damage $\ldots \ldots \ldots \ldots \ldots$ & 4 & 1 \\
\hline If landowners have to pay to protect or raise game & 80 & $2 \mathrm{I}$ \\
\hline If landowner is trying to improve hunting ........ & 44 & 12 \\
\hline Landowner should get something ....... & 72 & 19 \\
\hline To pay for hunter damages ....... & 44 & 12 \\
\hline If there is a lot of game $\ldots \ldots \ldots$ & 23 & 6 \\
\hline Landowners are charged in town & 12 & 3 \\
\hline Fees are presently being charged & 5 & 1 \\
\hline Landowners privilege ......... & 16 & 4 \\
\hline Miscellaneous reasons & 29 & 8 \\
\hline No comment ........ & 18 & 5 \\
\hline Total Landowners in Favor of Hunting Fees & 379 & $100^{\circ \circ}$ \\
\hline
\end{tabular}

Less than one-half of 1 per cent.
A few landowners gave more than one reason and the columns do not add to the totals. 
folks, hunting club members, deer hunters, and out-of-staters. At the same time this group of owners would like to exclude their friends and neighbors from such charges.

Second, there is a group of landowners who favor fees primarily for equity considerations. Among these owners, fees would be permissible and desirable if landowners are incurring costs to raise game, protect wildlife, improve the habitat, or to repair hunter damage. Included in this group are those landowners, about 20 per cent of those favoring fees, who believe that ownership of land, in itself, deserves a return. Also included in this category are those owners who favor charges because "they must pay for goods and services bought downtown." Further, this group includes those who would charge "if there is a lot of game." Presumably if there is an abundance of game, the landowner must have undergone some expense to bring about such a favorable situation.

Third, there is a small group of landowners who favor hunting fees primarily to restrict the total number of hunters.

\section{Willingness of Landowners to Charge Hunting Fees}

Although 27 per cent of all landowners believed that they should charge hunting fees, only 18 per cent indicated a willingness to do so when asked specifically if they would grant hunting privileges for a fee (Table 25). Of greater importance, however, is the 79 per cent of all landowners who would not be willing to grant hunting privileges for a fee. With such a large proportion of landowners indicating a reluctance to charge for hunting, it is unlikely that the transformation of what has traditionally been a free service into a marketable one with exchange value will take place in the near future.

It is possible, however, that the attitudes of some landowners regarding hunting fees are a result of practical considerations including both supply and demand features. The fairness or unfairness of assessing hunting fees, and willingness or unwillingness to make such charges, may seem ridiculous to an owner who has no wildlife on his land or an owner whose land is rarely, if ever, used for hunting.

\section{Landowner Estimates of Fees that Should be Assessed on Hunters}

The charging of hunting fees is such an unfamiliar phenomenon to West Virginia landowners that relatively few of them have any basis for estimating a size fee to assess hunters for using their land. As noted in Table 26, 54 per cent of those who would be willing to charge a fee do not know what size fee should be charged. Among those who indicated a fee size, $\$ 1.00$ per day was mentioned most often. Weekly, monthly, or seasonal fees were mentioned by so few landowners that they have been omitted from further consideration. 
TABLE 25

Willingness of landowners to charge a fee for hunting privileges, sample of West Virginia landowners, 1965

\begin{tabular}{|c|c|c|c|c|c|c|}
\hline \multirow[b]{2}{*}{ County } & \multicolumn{2}{|c|}{ Those Willing } & \multicolumn{2}{|c|}{ Those Not Willing } & \multicolumn{2}{|c|}{ No Opinion } \\
\hline & Number & Per Cent & Number & Per Cent & Number & Per Cent \\
\hline 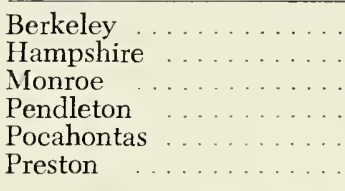 & $\begin{array}{r}6 \\
29 \\
13 \\
26 \\
10 \\
50\end{array}$ & $\begin{array}{r}8 \\
21 \\
12 \\
24 \\
11 \\
29\end{array}$ & $\begin{array}{r}70 \\
109 \\
88 \\
81 \\
79 \\
121\end{array}$ & $\begin{array}{l}92 \\
79 \\
82 \\
76 \\
87 \\
70\end{array}$ & $\begin{array}{l}0 \\
0 \\
6 \\
0 \\
2 \\
3\end{array}$ & $\begin{array}{l}0 \\
0 \\
6 \\
0 \\
2 \\
2\end{array}$ \\
\hline $\begin{array}{r}\text { EASTERN } \\
\text { REGION } \\
\end{array}$ & 134 & 19 & 548 & 79 & 11 & 2 \\
\hline $\begin{array}{l}\text { Fayette } \quad \ldots \ldots \ldots \ldots \\
\text { Lincoln } \ldots \ldots \ldots \ldots \\
\text { Wyoming } \ldots \ldots \ldots\end{array}$ & $\begin{array}{r}5 \\
13 \\
3\end{array}$ & $\begin{array}{r}10 \\
10 \\
9\end{array}$ & $\begin{array}{r}40 \\
114 \\
30\end{array}$ & $\begin{array}{l}83 \\
86 \\
91\end{array}$ & $\begin{array}{l}3 \\
5 \\
0\end{array}$ & $\begin{array}{l}6 \\
4 \\
0\end{array}$ \\
\hline $\begin{array}{l}\text { SOUTHERN } \\
\text { REGION }\end{array}$ & 21 & 10 & 184 & 86 & 8 & 4 \\
\hline $\begin{array}{l}\text { Braxton . . } \\
\text { Doddridge } \\
\text { Marshall } \\
\text { Roane }\end{array}$ & $\begin{array}{l}17 \\
23 \\
25 \\
30\end{array}$ & $\begin{array}{l}13 \\
25 \\
19 \\
20\end{array}$ & $\begin{array}{r}112 \\
68 \\
95 \\
115\end{array}$ & $\begin{array}{l}84 \\
75 \\
71 \\
78\end{array}$ & $\begin{array}{r}5 \\
0 \\
13 \\
3\end{array}$ & $\begin{array}{r}4 \\
0 \\
10 \\
2\end{array}$ \\
\hline $\begin{array}{l}\text { NORTHWESTERN } \\
\text { REGION }\end{array}$ & 95 & 19 & 390 & 77 & 21 & 4 \\
\hline All Regions ...... & 250 & 18 & 1,122 & 79 & 40 & 3 \\
\hline
\end{tabular}

\section{Brief Review of Landowner Attitudes on the Assessment of Hunting Fees}

In light of the data in Tables 22, 23, and 24, it is apparent that the traditional view of open and free hunting still prevails among most private landowners in West Virginia. At the same time, it is equally apparent that some inroads are being made in these older customs and attitudes. In the opinion of some landowners it is no longer a simple question of one's natural right to hunt upon another's land free of charge, but a question of equity. If costs are incurred by the landowner to provide these hunting grounds, then a hunting fee seems appropriate. Further, the notion seems to be developing that land itself deserves a return, no matter the effort being made by landowners to improve the quality of hunting. Finally, the changing attitudes on hunting fees are most visibly noted by the large number of landowners who either favor or would favor hunting fees if they could be assessed on everyone but their friends and neighbors.

Considering the widespread opposition to hunting fees that exists among landowners in West Virginia, it is not surprising to note that only 


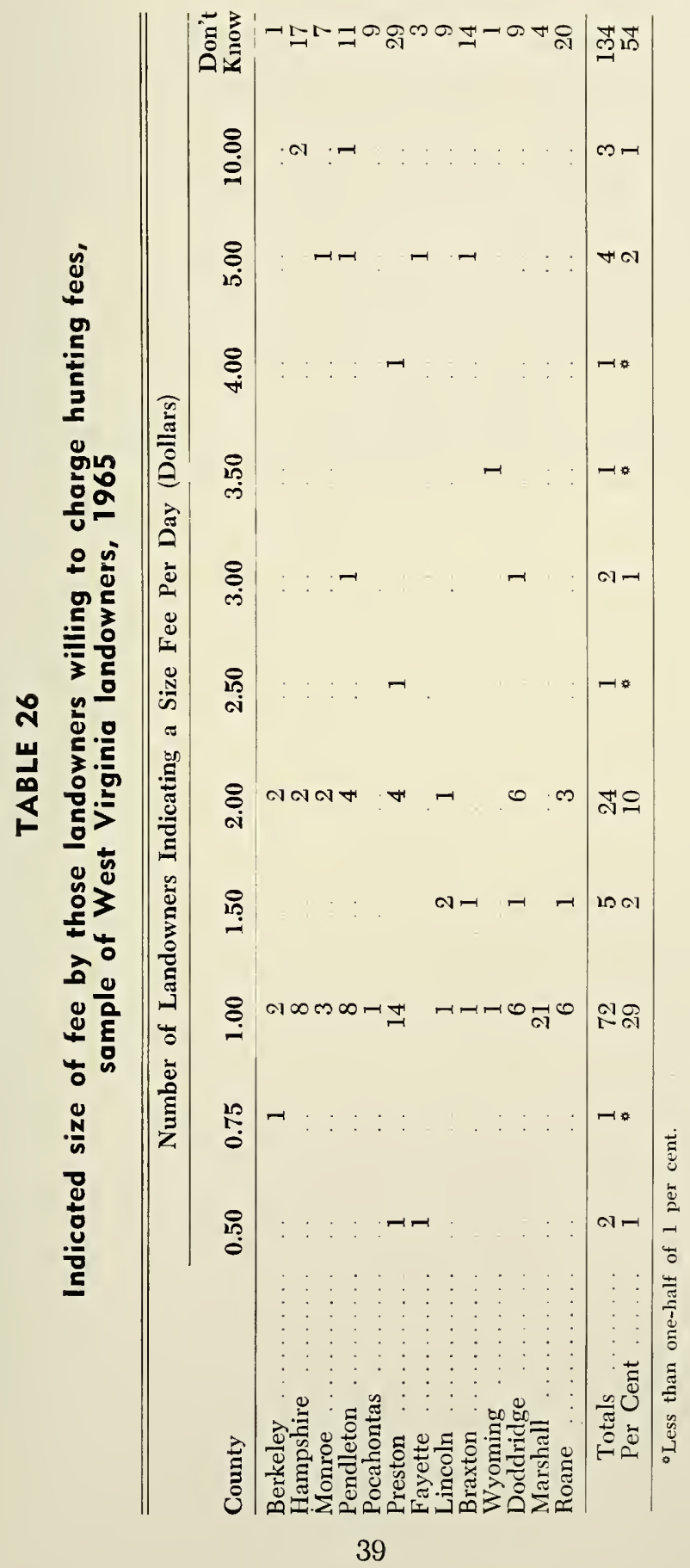


3 of 1,412 landowners are currently assessing fees on individual hunters (Table 20 ). Furthermore, it is not surprising to find that only 1 per cent of all landowners have contractural arrangements with hunting clubs whereby hunting rights on their land are leased for club members only. However, the fact that some landowners are marketing the hunting rights on their land is an indication that the traditional values are undergoing change, even though the change is not yet well established nor a major factor in the hunting scene of West Virginia.

Almost all of the landowners who are charging fees or leasing hunting rights are located in the Eastern region where the highest quality hunting lands are located. Among the counties surveyed, Hampshire, Berkeley, Preston, and Pocahontas are the ones where the evolution toward personal income from the marketing of hunting rights on privately owned land appears to be gathering greatest momentum. 





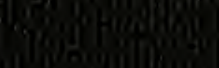

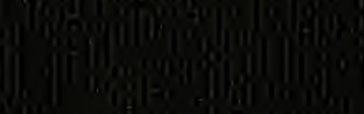

Cing

mongen

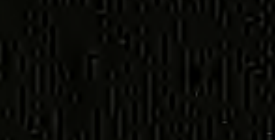

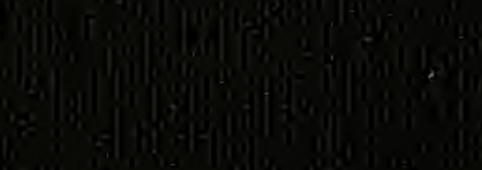

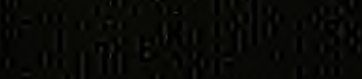

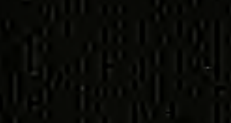

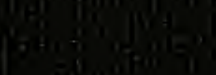

a.

mongen

biong

istong

sing

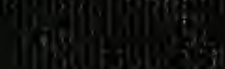

